\title{
Gaining knowledge on source contribution to aerosol optical absorption properties and organics by receptor modelling
}

\author{
A.C. Forello $^{\text {a }}$, F. Amato ${ }^{\mathrm{b}}$, V. Bernardoni ${ }^{\mathrm{a}}$, G. Calzolai ${ }^{\mathrm{c}}$, S. Canepari ${ }^{\mathrm{d}}$, F. Costabile $^{\mathrm{e}}$, \\ L. Di Liberto ${ }^{\mathrm{e}}$, M. Gualtieri ${ }^{\mathrm{f}}$, F. Lucarelli ${ }^{\mathrm{c}}$, S. Nava ${ }^{\mathrm{c}}$, C. Perrino ${ }^{\mathrm{g}}$, E. Petralia ${ }^{\mathrm{f}}$, S. Valentini ${ }^{\mathrm{a}}$, \\ G. Valli ${ }^{\text {a }}$, R. Vecchi ${ }^{\text {a,* }}$ \\ a Department of Physics, Università Degli Studi di Milano and INFN-Milano, 20133, Milan, Italy \\ ${ }^{\mathrm{b}}$ Institute of Environmental Assessment and Water Research (IDAA-CSIC), 08034, Barcelona, Spain \\ ${ }^{\mathrm{c}}$ Department of Physics and Astronomy, Università di Firenze and INFN-Firenze, 50019, Sesto Fiorentino, Italy \\ ${ }^{\mathrm{d}}$ Department of Chemistry, Sapienza University of Rome, 00185, Rome, Italy \\ ${ }^{\mathrm{e}}$ CNR-ISAC_Italian National Research Council, Institute of Atmospheric Science and Climate, 00133, Rome, Italy \\ ${ }^{\mathrm{f}}$ ENEA - SSPT - MET - Atmospheric Pollution Laboratory (INAT), 40129, Bologna, Italy \\ ${ }^{g}$ CNR-IIA-Italian National Research Council, Institute of Atmospheric Pollution Research, 00015, Monterotondo St, Rome, Italy
}

\section{A R T I C L E I N F O}

\section{Keywords:}

Advanced receptor modelling

Optical properties

Organic components

High time resolution

\begin{abstract}
A B S T R A C T
In this source apportionment study, an original approach based on receptor modelling was tested to relate primary and secondary organic aerosol (OA) contributions - estimated from ACSM (Aerosol Chemical Speciation Monitor) measurements - to their emission sources. Moreover, thanks to the coupling of optical and chemical variables as input to the receptor model, information such as the impact of mineral dust to the aerosol absorption in the atmosphere and estimates for the absorption Ångström exponent ( $\alpha$ ) of the sources were retrieved.

An advanced source apportionment study using the Multilinear Engine (ME-2) was performed on data collected during February 2017 in Rome (Italy), in the frame of the CARE (Carbonaceous Aerosol in Rome and Environs) experiment. A complete chemical characterisation (elements, non-refractory components, and carbonaceous components) was carried out, and the aerosol absorption coefficients $b_{a p}(\lambda)$ at 7 wavelengths (370, 470, 520, 590, 660, 880, and $950 \mathrm{~nm}$ ) were retrieved by an Aethalometer AE33; all these variables (chemical + optical) were used as input to the receptor model. The final constrained solution consisted of nine factors which were assigned to major sources impacting on the investigated site (hereafter sources are referred to as: biomass
\end{abstract}

\footnotetext{
* Corresponding author.

E-mail address: roberta.vecchi@unimi.it (R. Vecchi).
} 
burning, nitrate and aged aerosol, traffic exhaust, sulphate, mineral dust, marine aerosol, traffic non-exhaust, local source, and polluted marine aerosol), comprising both local urban sources and contributions from longrange transport. The bootstrap analysis supported the goodness of the solution.

Total OA concentration from ACSM was apportioned by our receptor model and afterwards compared with HOA (hydrocarbon-like organic aerosol), BBOA (biomass burning-like organic aerosol), and OOA (oxygenated organic aerosol) concentrations obtained as results from an independent source apportionment study previously performed. As an original result of this work, insights on OA contributions were thus retrieved: (1) the contribution of organic aerosol assigned by ME-2 to the traffic exhaust source was fully comparable to HOA assessed by ACSM data analysis; (2) our source apportionment results gave the relevant indication that the OOA apportionment made on ACSM data likely includes a secondary OA contribution due to biomass burning.

Other relevant results came from $b_{a p}$ apportionment obtained by our multi-variable source apportionment approach: traffic exhaust was the main contributor to aerosol absorption in the atmosphere, but mineral dust contribution was also notable when a not negligible mineral dust transport episode was registered at the measurement site. In addition, source dependent optical absorption parameters (i.e. the absorption Ångström exponent - $\alpha$ - and the mass absorption cross section at different wavelengths) were retrieved without any a-priori assumption.

In perspective, our modelling approach paves the way to more powerful source apportionment approaches which have the potential of providing much more insights on aerosol properties and sources.

\section{Introduction}

Atmospheric aerosol - or particulate matter, PM - impacts human health (WHO, 2018) and climate (IPCC, 2013). Aerosol source identification and quantification are mandatory to establish mitigation strategies with the aim of reducing particle concentrations in the atmosphere; in this framework, receptor models are widely used for PM source apportionment (Hopke, 2016). Among them, the Positive Matrix Factorization (PMF) is a weighted least square method based on non-negativity constraints (Belis et al., 2019a), where an array of data can be written as the sum of products of unknown variables (Paatero, 1999). The Multilinear Engine (ME-2) is a very flexible algorithm developed to solve PMF problems generally defined as multilinear mathematical expressions; the flexibility of ME-2 allows the implementation of advanced approaches, e.g. the multi-time resolution model (Zhou et al., 2004; Ogulei et al., 2005; Crespi et al., 2016; Forello et al., 2019). High-time resolution measurements allow the investigation of short-scale processes in the atmosphere; their exploitation as input data to receptor modelling helps in the identification of sources so that high time resolution temporal patterns of the sources and also episodic emissions can be retrieved.

Over the last decades, the development of high time resolution aerosol mass spectrometers has allowed an increasing detailed chemical and physical characterisation of atmospheric aerosol (Canagaratna et al., 2007); indeed, atmospheric single particles are constituted by millions of molecules, giving a very large signal for mass spectrometers (Murphy, 2007). In recent years, on-line mass spectrometers like the HR-AMS (High Resolution Aerosol Mass Spectrometry) and the ACSM (Aerosol Chemical Speciation Monitor) were proved to be capable of routine stable operation for long periods of time (Ng et al., 2011). The huge amount of data produced can be processed via positive matrix factorization (Ulbrich et al., 2009; Canonaco et al., 2013). PMF analysis on organic fragments was useful to further classify groups of organic aerosol components like HOA (hydrocarbon-like organic aerosol), BBOA (biomass burning-like organic aerosol), and OOA (oxygenated organic aerosol) (Fröhlich et al., 2015) based on their chemical affinity (DeCarlo et al., 2010). In this way, primary and secondary organic contributions can be distinguished, but the origin of secondary aerosol components remains difficult to assess. At the state of the art, few source apportionment studies combine high time resolution measurements of the organic aerosol fraction with the inorganic one retrieved by other analytical techniques (Sofowote et al., 2018; Belis et al., 2019b; Jeong et al., 2019).

Following the original approach described in Forello et al. (2019), in this work a high-time resolution dataset comprising both organic and inorganic chemical species and the multi-wavelength aerosol absorption coefficients was used as input to the advanced receptor model. The interest for such a detailed dataset lies in the possibility of a further test on the approach above mentioned in a case-study characterised by aerosols with a variety of properties and sources and - in particular - impacted by episodes occurring on short timescales. In addition, from this dataset as far as we know, here for the first time - the model retrieved the optical absorption contribution and absorption Ångström exponent of mineral dust. Last but not least, results from the ME-2 analysis were compared with ACSM separation of the organic aerosol fraction obtaining the relevant indication that the OOA apportionment made on ACSM data likely includes a secondary OA contribution due to biomass burning.

\section{Material and methods}

\subsection{Site description}

The CARE (Carbonaceous Aerosol in Rome and Environs) measurement campaign was carried out in Rome (Italy; latitude: $41.88^{\circ}$, longitude: $12.49^{\circ}$ ), in the middle of the Mediterranean sea, at an urban background site from 1st to February 28, 2017. Due to its position and meteorological conditions, the site can be affected by long-range transport of air masses from the sea - Rome is about $30 \mathrm{~km}$ from the nearest coast - and from the Sahara desert, but also from local urban sources (Valentini et al., 2020; and references therein).

\subsection{Online and offline measurements}

A detailed description of the equipment deployed during the CARE experiment is reported in Costabile et al. (2017a). In the following, only instrumentation relevant to the data used in this paper are summarised.

\subsubsection{Mass}

Hourly $\mathrm{PM}_{2.5}$ mass concentration was reconstructed from particle number size distribution (PNSD) data measured combining a scanning mobility particle sizer and an aerodynamic particle sizer (Costabile et al., 2019). Size distributions from these instruments were merged following the methodology reported in Khlystov et al. (2004) and a size-dependent effective particle density was used to obtain the mass. Details on the mass retrieval procedure and validation can be found in Costabile et al. (2017a) and Alas et al. (2019).

\subsubsection{Elemental composition}

Hourly $\mathrm{PM}_{2.5}$ samples were collected by a streaker sampler (D'Alessandro et al., 2003; Calzolai et al., 2015). Briefly, the streaker sampler collects with 1-h resolution aerosol particles in the coarse $\left(\mathrm{PM}_{2.5-10}\right)$ and fine $\left(\mathrm{PM}_{2.5}\right)$ fraction on an impaction stage and a filter, 
respectively. For the aim of this campaign, only the fine fraction was analysed by Particle Induced X-ray Emission (PIXE) technique to obtain the elemental composition. More details about the technique and the set-up can be found e.g. in Lucarelli et al. (2014) and Calzolai et al. (2015). Minimum detection limits (MDLs) of the technique were in the range $1-10 \mathrm{ng} \mathrm{m}^{-3}$ (depending on the element) and average experimental uncertainties for different species ranged from about $10 \%$ to about $40 \%$ (the latter refers to those elements measured with concentrations near MDL).

\subsubsection{Non-refractory chemical components}

Major non-refractory at $600{ }^{\circ} \mathrm{C}$ components in $\mathrm{PM}_{1}$ were measured by an Aerodyne aerosol chemical speciation monitor (ACSM, see e.g. $\mathrm{Ng}$ et al., 2011) with a temporal resolution of $30 \mathrm{~min}$. Shortly, in the ACSM particles are focused inside the instrument by a system of aerodynamic lenses, then thermally vaporised, and finally ionized by electron impact. Starting from the acquired mass spectrum, organic matter (OA), sulphate $\left(\mathrm{SO}_{4}^{2-}\right)$, ammonium $\left(\mathrm{NH}_{4}^{+}\right)$, nitrate $\left(\mathrm{NO}_{3}^{-}\right)$, and chloride $\left(\mathrm{Cl}^{-}\right)$ concentrations can be assessed. In a previous work (Costabile et al., 2017a), from ACSM data three factors for OA were singled out: HOA (hydrocarbon-like organic aerosol), BBOA (biomass burning-like organic aerosol), and OOA (oxygenated organic aerosol).

MDLs were estimated following $\mathrm{Ng}$ et al. (2011) as $0.105 \mu \mathrm{g} \mathrm{m}^{-3}$, $0.201 \mu \mathrm{g} \mathrm{m}^{-3}, 0.017 \mu \mathrm{g} \mathrm{m}^{-3}, 0.008 \mu \mathrm{g} \mathrm{m}^{-3}$, and $0.008 \mu \mathrm{g} \mathrm{m}^{-3}$ for OA, $\mathrm{NH}_{4}^{+}, \mathrm{SO}_{4}^{2-}, \mathrm{NO}_{3}^{-}$, and $\mathrm{Cl}^{-}$, respectively. Sensitivity tests using different ranges of trial uncertainties as input to the model were performed; in the end, average uncertainties for ACSM measurements were set to $19 \%$ for $\mathrm{OA}, 36 \%$ for $\mathrm{NH}_{4}^{+}, 28 \%$ for $\mathrm{SO}_{4}^{2-}$, and $15 \%$ for $\mathrm{NO}_{3}^{-}$, in accordance with the reproducibility relative uncertainties observed in ACSM intercomparison exercises (Crenn et al., 2015; Belis et al., 2019b).

\subsubsection{Carbonaceous components}

Elemental carbon (EC) and organic carbon (OC) concentrations with $2 \mathrm{~h}$ resolution were obtained by a Sunset Field Thermal-Optical Analyser (Sunset Laboratory Inc.). Briefly, this instrument collects particles on a quartz fibre filter; at the end of each sampling period (105 min of sampling and $15 \mathrm{~min}$ of analysis) the collected sample is analysed with the NIOSH-like temperature protocol (Sunset Laboratory Inc, 2005). The inlet was equipped with a cyclone with a cut point of $2.5 \mu \mathrm{m}$ and a denuder for organics. MDL was $0.240 \mu \mathrm{g} \mathrm{m}^{-3}$ for OC and EC concentrations. Average uncertainties used as input to the model were $15 \%$ and $10 \%$ for EC and OC concentrations, respectively.

\subsubsection{Optical absorption coefficients}

Optical properties were retrieved by online instrumentation with a time resolution of $1 \mathrm{~min}$.

The aerosol absorption coefficient $b_{a p}(\lambda)$ at 7 wavelengths $(370,470$, $520,590,660,880$, and $950 \mathrm{~nm}$ ) was retrieved in $\mathrm{PM}_{10}$ by a dual-spot Aethalometer (AE33, Magee Scientific) (Drinovec et al., 2015) using the instrument specific mass absorption cross-sections (MACs) (Magee Scientific AE33 User Manual, 2016) and the measured equivalent black carbon $(\mathrm{eBC})$ concentration. $\mathrm{b}_{\mathrm{ap}}(\lambda)$ values are calculated by the AE33 internal software considering attenuation measurements corrected for loading ( $\mathrm{k}$ parameter) and multiple scattering (C factor) effects. It is noteworthy that recent literature studies (e.g. Goetz et al., 2018) evidenced that the fixed $\mathrm{C}$ factor equal to 1.57 typically used in AE33 can lead to a significant overestimation of the $b_{a p}(\lambda)$. Therefore, in this work a $\mathrm{C}$ factor of 2.66 was used at all wavelengths, as previously estimated by Valentini et al. (2020) for the CARE campaign.

MDLs were estimated in the range $0.36-0.92 \mathrm{Mm}^{-1}$ depending on the wavelength and average experimental uncertainty on $b_{a p}(\lambda)$ was 15\% (U.S. EPA, 2011).

\subsection{Model description}

Receptor models rely on the principle of mass conservation between the emission source and the receptor site. Among them, the positive matrix factorization (PMF) is based on uncertainty-weighted pollutant measurements to find the best linear combination of factors influencing atmospheric concentrations (Paatero and Tapper, 1994; Hopke, 2016; Belis et al., 2019a).

The basic bilinear equation to be solved is the following:

$x_{i j}=\sum_{k=1}^{P} g_{i k} f_{k j}+e_{i j}$

where the input data matrix $X$ (matrix elements $x_{i j}$ ) is decomposed in the product of two factor matrices $F$ (matrix elements $f_{k j}$ ) and $G$ (matrix elements $g_{i k}$ ), related to factors chemical profiles and factors temporal contribution, respectively; factors can be then interpreted as the main sources impacting the investigated area. The matrix $E$ (matrix elements $e_{i j}$ ) is composed of the residuals, i.e. the difference between measured and modelled values. Indices $i, j$, and $k$ indicate the sample, the species, and the factor, respectively; $P$ is the total number of factors.

The solution of the problem is obtained minimising the object function $\mathrm{Q}$, that is defined as:

$Q=\sum_{i} \sum_{j}\left(\frac{x_{i j}-\sum_{k=1}^{P} g_{i k} f_{k j}}{\sigma_{i j}}\right)^{2}=\sum_{i} \sum_{j}\left(\frac{e_{i j}}{\sigma_{i j}}\right)^{2}$

where the elements $\sigma_{i j}$ of the matrix $\sigma$ are the uncertainties related to $x_{i j}$, and they are given as input data together with $x_{i j}$. The minimisation is performed under the constraint that elements of $G$ and $F$ are nonnegative. Therefore, from the application of this modelling approach the chemical profiles and temporal patterns contributions of the identified sources as well as the average source apportionment are retrieved at the receptor site.

The Multilinear Engine program ME-2 (Paatero, 1999) was developed to solve PMF and - specifically - more general multilinear problems; ME-2 flexibility allows to solve problems even more complicated than the bilinear one presented in Eq. (1). In the case of the multi-time resolution model applied in this work, modifications to Eq. (1) are needed to exploit data with different time resolutions in the same source apportionment analysis. This advanced receptor modelling approach pioneered by Zhou et al. (2004) - can be developed through the Multilinear Engine ME-2 script in order to use experimental data with different time resolutions in the same source apportionment study (Ogulei et al., 2005; Liao et al., 2013, 2015; Kuo et al., 2014; Crespi et al., 2016; Sofowote et al., 2018; Srivastava et al., 2019; Forello et al., 2019).

In the multi-time approach, Equation (1) is modified as reported below:

$x_{s j}=\frac{1}{t_{s 2}-t_{s 1}+1} \sum_{k=1}^{P} f_{k j} \sum_{i=t_{s 1}}^{t_{s 2}} g_{i k} \eta_{j m}+e_{s j}$

where the indices $s, j$, and $k$ represent the sample, the species, and the factor, respectively; $P$ is the number of factors; $t_{s 1}$ and $t_{s 2}$ are the start and end times for the sth sample expressed in time units (i.e. the shortest sampling interval); $i$ represents the time unit of the sth sample. $x_{s j}$ is an element of the input matrix $X, f_{k j}$ is an element of the matrix $F$ (i.e. chemical profiles), $g_{i k}$ is an element of the matrix $G$ (i.e. time contributions) and $e_{s j}$ is an element of the residual matrix $E$ (i.e. differences between measured and modelled values). $\eta_{j m}$ is an adjustment factor for replicated species measured with different analytical methods (represented by subscript $m$ ) and with different time resolutions (all $\eta_{j m}$ set to one in our case, see Sect. 2.4).

The following regularisation equation is also introduced in the multitime model to smooth the time series contributions:

$g_{(i+1) k}-g_{i k}=0+\varepsilon_{i}$ 
where $\varepsilon_{i}$ are the residuals of this equation. Equations (3) and (4) are solved using the ME-2 program (Paatero, 1999), minimising the object function $\mathrm{Q}$ defined as the squared sum of the uncertainty-scaled residuals (see Sect. S2 in the Supplement for more details).

In this work, a physical constraint based on a mass balance equation was implemented and solved together with Eq. (3) and Eq. (4) in the multi-time model; in each factor, the sum of concentrations of the species must be equal or smaller than the total variable mass concentration. The equation for each factor was introduced in the general form (Paatero and Hopke, 2009):

$0=\sum_{j=1}^{N} c_{j} f_{k j}+r_{v}$

where $N$ is the number of species, $c_{j}$ are known numerical coefficients, and $r_{v}$ represents the residual of the auxiliary equation. In this equation the numerical coefficient for mass is $c_{\text {mass }}=+1$, while for species other than mass $c_{j}=-1$. Since contributions from not measured oxides and water can be present, the equation was implemented in order to allow negative values of the residual $r_{v}$ (using error model code $=-17$, see Sect. S2 in the Supplement for details).

The multi-time resolution model implemented by Crespi et al. (2016) was used as a basis as it allows the estimation of uncertainties by bootstrap analysis (see Sect. 3.1).

\subsection{Input data}

In this work, $1 \mathrm{~h}$ was chosen as the basic time unit in the model to study high time resolution changes in source emissions. As already mentioned in Sec. 2.3, adjustment factors $\eta_{j m}$ in Eq. (3) were set to one, since no replicated species were present in this dataset after input data selection (selection criteria are explained hereafter).

In order to reduce their relevance in the modelling process, mass concentrations were included in the model with uncertainties set at 4 times their values following Kim et al. (2003). All other variables were classified according to their signal-to-noise ratio ( $\mathrm{S} / \mathrm{N})$ as suggested by Paatero (2015). All strong variables $(S / N \geq 1.2)$ and only some weak variables (i.e. $\mathrm{Ti}, \mathrm{V}, \mathrm{Rb}$, and $\mathrm{Pb}$ ) were used as input to the model. In the literature, $\mathrm{Ti}, \mathrm{V}, \mathrm{Rb}$, and $\mathrm{Pb}$ are often indicated as tracers of specific sources (Saharan dust advection for Ti, residual oil combustion for $\mathrm{V}$, biomass burning for $\mathrm{Rb}$, and industry for $\mathrm{Pb}$ ); for this reason, they were taken into account although strongly underweighted multiplying their uncertainties by a factor 3 . Ranges of uncertainties and MDLs for measured variables are reported in Sect. 2.2; in the input dataset, uncertainties and data below minimum detection limits were pre-treated according to Polissar et al. (1998). Missing values were substituted by linear interpolation, with uncertainties set as three times the interpolated concentration value. Among strong variables, Si showed a slightly higher percentage $(26 \%)$ of missing data due to blank filter contamination. Linear interpolation was not possible in this case, since missing data were consecutive over time; therefore, in order to avoid artificial high values in modelled time contributions as already reported in literature works (Zhou et al., 2004; Forello et al., 2019), missing values were substituted by the median value calculated over the whole campaign, with uncertainties set at four times the median value.

To avoid double counting for sulphur/sulphate, organic aerosol/ organic carbon, and chlorine/chloride the selection of input data was performed as explained in the following.

Atmospheric concentrations of $\mathrm{SO}_{4}^{2-}$ (measured online by ACSM) and S (measured offline by PIXE analysis on streaker samples) display very similar temporal patterns. The linear regression shows a slope of $2.54 \pm 0.02\left(\mathrm{R}^{2}=0.89\right)$ (Fig. 1S in the Supplement). The difference of about $15 \%$ from the sulphate-to-sulphur stoichiometric value (equal to 3 ) is within average uncertainties ( $12 \%$ for $\mathrm{S}$ and $28 \%$ for $\mathrm{SO}_{4}^{2-}$ ), and can be mainly ascribed to different sampling and analytical techniques (for more details see Sect. $1 \mathrm{~S}$ in the Supplement). In order to avoid double counting, $\mathrm{SO}_{4}^{2-}$ measured by ACSM was chosen as input variable, because sulphate is very often in the form of ammonium sulphate and $\mathrm{NH}_{4}^{+}$was measured by ACSM as well.

Atmospheric concentrations of organic aerosol OA (measured online by ACSM) and organic carbon OC (measured online by Sunset Field Thermal-Optical Analyser) show very similar temporal patterns, too (Fig. 3S in the Supplement). The 2-h median value of OA-to-OC ratio is 1.3 (1.1 and 1.5 are the limits of the interquartile range) that is lower than 1.6 used in previous literature studies performed in Rome (Perrino et al., 2009, 2016; Tofful and Perrino, 2015); also in this case it is likely due to different sampling and analytical techniques. Finally, OA was selected as input variable since it carries a larger fraction of the total mass.

As for $\mathrm{Cl}$ (measured by PIXE analysis) and $\mathrm{Cl}^{-}$(given by ACSM) concentrations, the former was used as input variable to the model as it showed much more reliable temporal pattern and concentration.

$\mathrm{b}_{\mathrm{ap}}(\lambda)$ values measured at 7 wavelengths in $\mathrm{PM}_{10}$ were inserted in the model together with chemical variables assessed in $\mathrm{PM}_{2.5}$ (and $\mathrm{PM}_{1}$ for ACSM data). The main issue in considering different size fractions for chemical and optical variables was the presence of a desert dust transport episode (Valentini et al., 2020) lasting less than two days (24th 25th February) during the CARE campaign. In this work, samples impacted by desert dust were included in the input dataset in order to estimate optical absorption properties of the mineral dust source (see Sect. 3.2). It is interesting to note that in the simulation chamber study by Caponi et al. (2017), desert dust samples in the $\mathrm{PM}_{10}$ and $\mathrm{PM}_{2.5}$ fractions showed very small differences in elemental composition and the absorption Ångström exponent $(\alpha)$ of dust in that work did not seem to be related to differences in particle size.

Forello et al. (2019) have shown the usefulness of performing a source apportionment study on a dataset joining chemical and optical variables; indeed, source-dependent $\alpha$ values and mass absorption cross-sections (MACs) at different wavelengths can be retrieved by the model, without any a-priori assumption (see Sect. 3.2). As for the MAC of mineral dust, in Caponi et al. (2017) it was defined considering the total mass concentration of dust and, opposite to the $\alpha$ value, the MAC seemed to be dependent on particle size. For this reason, the MAC values at different wavelengths retrieved in this work for mineral dust have to be considered as an upper limit.

Finally, 30 variables with 1 -h resolution $\left(\mathrm{PM}_{2.5}\right.$ mass, $\mathrm{Na}, \mathrm{Mg}, \mathrm{Al}, \mathrm{Si}$, $\mathrm{Cl}, \mathrm{K}, \mathrm{Ca}, \mathrm{Ti}, \mathrm{V}, \mathrm{Cr}, \mathrm{Mn}, \mathrm{Fe}, \mathrm{Ni}, \mathrm{Cu}, \mathrm{Zn}, \mathrm{Br}, \mathrm{Rb}, \mathrm{Pb}, \mathrm{OA}, \mathrm{NH}_{4}^{+}, \mathrm{SO}_{4}^{2-}, \mathrm{NO}_{3}^{-}$, $\mathrm{b}_{\mathrm{ap}}$ at $370 \mathrm{~nm}, 470 \mathrm{~nm}, 520 \mathrm{~nm}, 590 \mathrm{~nm}, 660 \mathrm{~nm}, 880 \mathrm{~nm}$, and $950 \mathrm{~nm}$ ) and 2-h EC concentrations were inserted as input data in the multi-time model. The input matrix $X$ consisted of 916 samples distributed over 619 time units. The analysis was performed in the robust mode (Brown et al., 2015). The error model em $=-14$ was used for the main equation with $\mathrm{C}_{1}$ = input error, $\mathrm{C}_{2}=0.0$, and $\mathrm{C}_{3}=0.1$ (Paatero, 2012) for both chemical and optical absorption data (see Sect. S2 in the Supplement for more details).

It is important to remark that, in contrast to what generally believed, the analysis of matrices with different dimensional units (in this work, $\mathrm{Mm}^{-1}$ for optical absorption variables, and $\mathrm{ng} \mathrm{m}^{-3}$ for chemical variables) is not a priori adversely affected by these differences, as underlined by Paatero (2018) and shown by results reported in Forello et al. (2019).

\section{Results and discussion}

\subsection{Source apportionment coupling different datasets}

Following the approach proposed by Forello et al. (2019), the model was run coupling chemical variables and light absorption coefficients at 7 wavelengths retrieved by AE33 Aethalometer. Solutions from 5 to 10 factors were explored. In this analysis 30 convergent runs were obtained and a nine-factor base case solution corresponding to the minimum $Q$ value was selected. A lower or higher number of factors gave mixing or 
artificial separation of sources, respectively, and a not satisfactory reconstruction of some variables during aerosol transport episodes (e.g. marine aerosol advection). In the selected base-case solution, all variables were well reconstructed by the model $\left(R^{2}>0.70\right)$ with the exception of $\mathrm{V}\left(\mathrm{R}^{2}=0.52\right)$ and $\mathrm{Ni}\left(\mathrm{R}^{2}=0.51\right)$, that were however characterised by concentration values near MDLs. Uncertainty-scaled residuals (as defined in Paatero and Tapper, 1994, and Norris et al., 2014) were randomly distributed in the \pm 3 range and their distribution was mostly symmetrical. The explained variation for matrix F (EVF) (see Lee et al., 1999, and Paatero, 2010 for the definition) was firstly exploited for factor-to-source assignment; indeed, high EVF values are typically indicators for chemical species which are source tracers. The unexplained variation for matrix $\mathrm{F}$ was lower than 0.15 for all variables.

In Fig. 4S in the Supplement, EVF and chemical profiles for the basecase solution are reported. According to EVF, chemical profile, and temporal trend, the nine factors were tentatively assigned to biomass burning, nitrate and aged aerosol, traffic exhaust, sulphate, mineral dust, marine aerosol, traffic non-exhaust, local source, and polluted marine aerosol (see also afterwards for details on the factor-to-source assignment motivation). In Table $1 \mathrm{~S}$ in the Supplement, average source contributions to atmospheric $\mathrm{PM}_{2.5}$ mass are reported both in absolute and percentage values.

Even if the base-case solution is largely satisfactory, constrained solutions were explored and finally constraints were applied to the factor interpreted as marine aerosol. Indeed, the marine aerosol factor in the base-case solution was characterised by values of the typical diagnostic ratios $\mathrm{Mg} / \mathrm{Na}$ and $\mathrm{Cl} / \mathrm{Na}$ very similar to literature ones for bulk sea salt emissions (Seinfeld and Pandis, 2006), suggesting advection of fresh marine aerosol. However, contaminations appeared in the chemical profile due to EC, together with $\mathrm{NH}_{4}^{+}$and $\mathrm{NO}_{3}^{-}$, which are often found in chemical profiles of aged marine emissions (Seinfeld and Pandis, 2006). From source temporal patterns, it was noted that the polluted marine aerosol episode was interrupted for a few hours by the advection of fresh marine aerosol; the former was characterised also by ship emissions so that some mixing between the two chemical profiles can be present. Therefore, in the constrained solution $\mathrm{EC}, \mathrm{NO}_{3}^{-}$, and $\mathrm{NH}_{4}^{+}$ were pulled down maximally in the chemical profile of marine aerosol (fresh); as a consequence, also $b_{a p}$ at all wavelengths decreased in agreement with the lack of light absorbing components in the profile. It is noteworthy that $\mathrm{NO}_{3}^{-}$contribution appeared in the polluted marine aerosol chemical profile, as expected when compounds present in marine air masses react with polluted air masses during the transport, leading also to chloride deficit (Seinfeld and Pandis, 2006).

Constraints led to an effective increase in $\mathrm{Q}$ of about 25 units with a $0.6 \%$ increase, which can be considered acceptable (Paatero and Hopke, 2009). The constrained solution improved the chemical profiles of factors impacted by sea salt, with negligible differences in all other relevant features (i.e. EVF, residuals, source apportionment) respect to the base-case one. Thus, the constrained solution was considered the most reliable one from a physical point of view; results are presented in Fig. 1 and Fig. 2 and discussed in the following. The average apportionment

Table 1

Absolute and relative average source apportionment in the nine-factor constrained solution; in parentheses, the 10th and 90th percentiles from the bootstrap analysis are reported.

\begin{tabular}{|c|c|c|}
\hline Factors - Sources & $\mu \mathrm{g} \mathrm{m}^{-3}$ & $\%$ \\
\hline F1 - Biomass burning & $5.5(4.5-5.8)$ & $32(26-34)$ \\
\hline F2 - Nitrate and aged aerosol & $4.4(3.7-5.2)$ & $25(22-30)$ \\
\hline F3 - Traffic exhaust & $2.8(2.6-3.2)$ & $16(15-18)$ \\
\hline F4 - Sulphate & $2.5(2.1-2.8)$ & $14(12-16)$ \\
\hline F5 - Mineral dust & $0.66(0.57-0.71)$ & $3.8(3.3-4.1)$ \\
\hline F6 - Marine aerosol & $0.63(0.50-0.74)$ & $3.6(2.9-4.2)$ \\
\hline F7 - Traffic non-exhaust & $0.38(0.26-0.51)$ & $2.2(1.5-2.9)$ \\
\hline F8 - Local source & $0.33(0.25-0.63)$ & $1.9(1.4-3.7)$ \\
\hline F9 - Polluted marine aerosol & $0.28(0.20-0.81)$ & $1.6(1.1-4.6)$ \\
\hline
\end{tabular}

during the CARE experiment is reported in Table 1.

Factor 1 was identified as biomass burning because it was characterised by high EVF for OA (0.57), $\mathrm{Rb}(0.51)$, and $\mathrm{K}(0.54)$ (Amato et al., 2016; Reid et al., 2005). In the chemical profile, OA concentration contributed for $81 \%$ of the total mass apportioned to the source; the second highest contribution was $13 \%$ given by $\mathrm{NO}_{3}^{-}$, followed by $\mathrm{K}$ (2.5\%), EC (1.7\%), and $\mathrm{SO}_{4}^{2-}(1.3 \%)$. Rb was less relevant in terms of mass contribution (about $0.01 \%$ ). The biomass burning source had a dominant contribution during the night, with highest values in the time interval 23:00-02:00 LT (temporal pattern in Fig. 2). Perrino et al. (2019) already highlighted a similar temporal behaviour of levoglucosan concentrations (tracer of biomass burning emissions) in wintertime in the city centre of Rome; it was likely related to biomass burning products originated in the peri-urban area and then transported towards the city centre. The biomass burning primary contribution to $\mathrm{PM}_{2.5}$ estimated by Perrino et al. (2019) was in the range 7.2\%-23.3\% during 2013-2016 winter months. In this work, the biomass burning source explained $32 \%$ of the $\mathrm{PM}_{2.5}$ mass, a bit higher than the previous estimate as also aged organic aerosol contribution was accounted for as explained in Sect. 3.3. Influence of aerosol ageing in a chemical profile of biomass burning from PMF was already reported in the literature (Piazzalunga et al., 2011).

Factor 2 was related to a source called nitrate and aged aerosol. In fact, $\mathrm{NO}_{3}^{-}$and $\mathrm{NH}_{4}^{+}$showed EVF of 0.65 and 0.44 , respectively, and non negligible EVF values were also found for $\mathrm{K}, \mathrm{Zn}, \mathrm{Rb}$, and $\mathrm{OA}$. This observation suggested that, as already found in factor 1 , the chemical profile of factor 2 showed some mixed contributions from biomass burning and nitrate. However, nitrate formation at urban sites is expected mainly from $\mathrm{NO}_{\mathrm{x}}$ traffic emissions thus justifying the share of $\mathrm{EC}$ in the chemical profile ( $4.7 \%$ of the apportioned mass, higher than in the biomass burning one) and the optical absorption contribution (see Sect. 3.2). The average mass contribution of this factor was $25 \%$.

Factor 3 was characterised by very high EVF (0.74) for EC and the only other significant chemical component in terms of EVF was $\mathrm{Fe}$ (0.35). The mass contribution of this source was ascribed to two major contributors, i.e. EC and OA accounting together for about $96 \%$ of the apportioned mass. The factor was thus identified as traffic (exhaust emissions) and impacted, on average, for $16 \%$ of the $\mathrm{PM}_{2.5}$ mass. Peaks in concentration values appeared in the evening approximately at 22:00 LT (Fig. 2). Similar traffic emission concentration patterns were previously observed in Rome, independently of the season, and they were associated to boundary layer dynamics (Struckmeier et al., 2016). The observed modulation was also confirmed by the temporal pattern of natural radioactivity due to Radon progeny detected in the atmosphere during the CARE campaign (Fig. 3; details in Costabile et al., 2017a); as well known, measurements of natural radionuclides can be used to trace the temporal evolution of atmospheric dispersion in the boundary layer and estimates for the mixing layer height (see e.g. Salzano et al., 2016; Vecchi et al., 2019; and references therein). The traffic (exhaust) source is the main contributor to aerosol light absorption in the atmosphere, confirming the factor-to-source assignment (see Sect. 3.2).

Factor 4 was assigned to sulphate, since $\mathrm{SO}_{4}^{2-}$ and $\mathrm{NH}_{4}^{+}$showed high EVF. V and Ni were characterised by EVF slightly higher than the other elements, suggesting some mixing with ship emissions. In terms of mass, the most significant contribution in the chemical profile was given by $\mathrm{OA}(14 \%)$ after $\mathrm{SO}_{4}^{2-}$ and $\mathrm{NH}_{4}^{+}$(63\% when added together). During the campaign, the average mass apportionment of this source was $14 \%$.

Factor 5 was associated to the mineral dust source because of high EVF for $\mathrm{Al}(0.88)$, $\mathrm{Ti}(0.86), \mathrm{Si}(0.82)$, and $\mathrm{Mg}(0.34)$. These variables are all crustal elements and tracers for mineral dust; it is noteworthy that the diagnostic ratios between these elements apportioned in the chemical profile are consistent with literature values (Amato et al., 2016). During the CARE campaign, a desert dust transport episode lasting less than two days (24th - 25th February) was clearly identified exploiting optical properties (Valentini et al., 2020). Even if the impact of desert dust was dominant in this factor - with concentration values as high as 25 times 

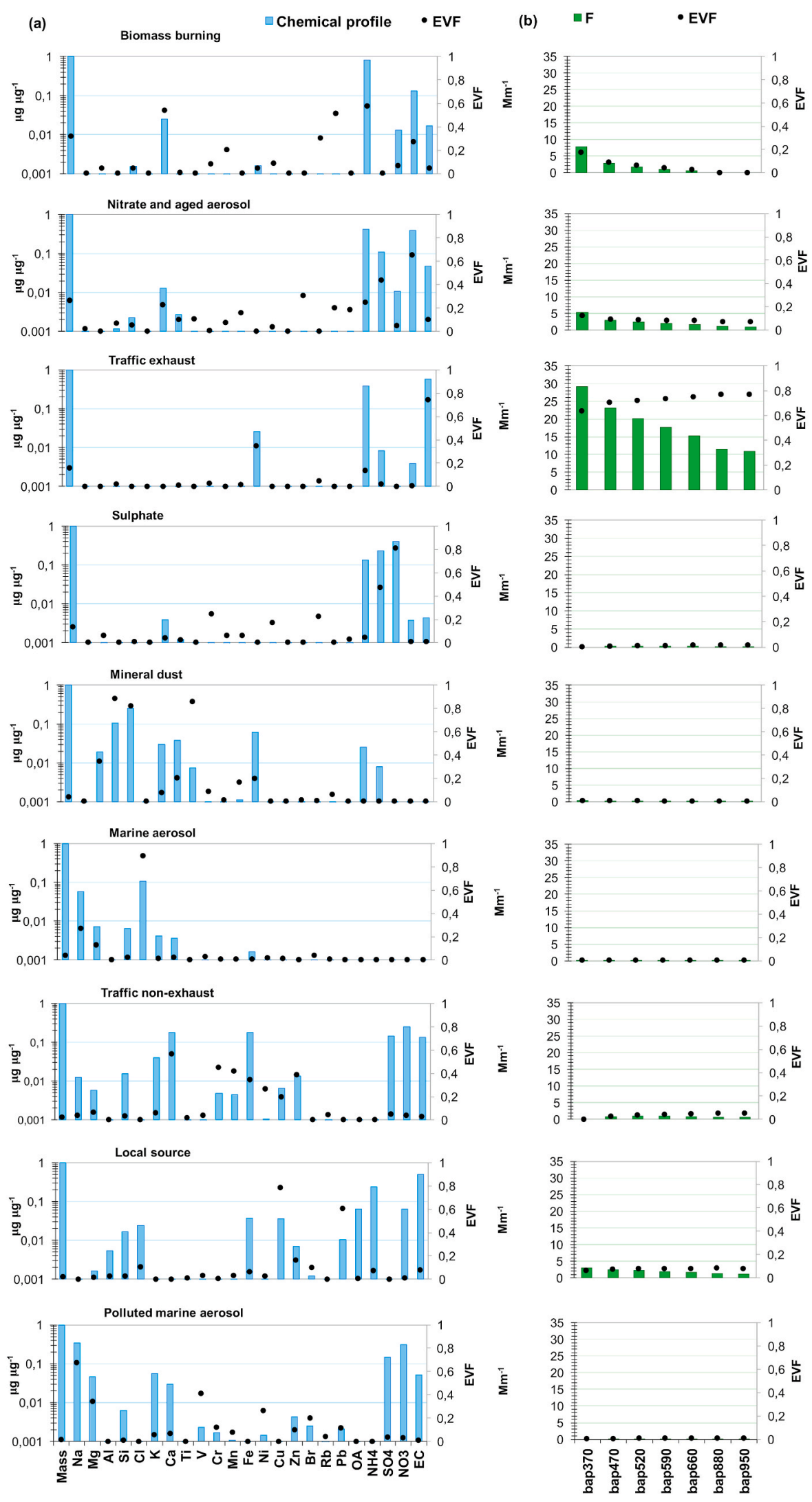

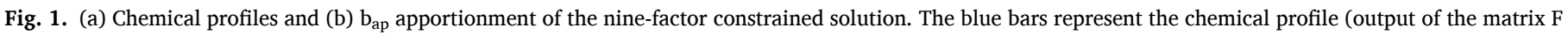

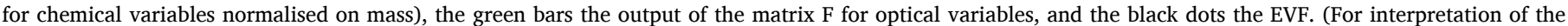
references to colour in this figure legend, the reader is referred to the Web version of this article.) 
Biomass burning

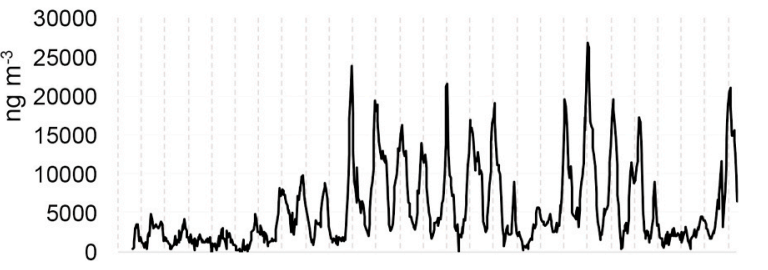

Traffic exhaust

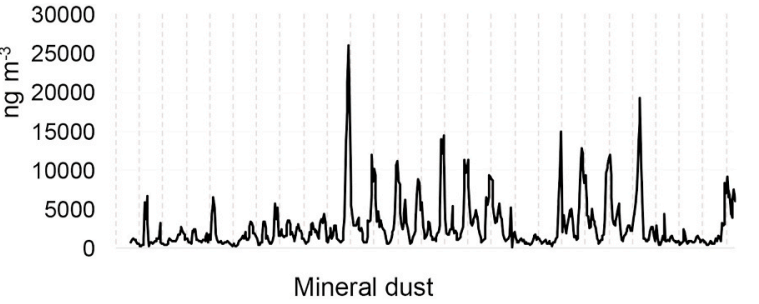

20000

है 16000

ㅁ 12000

8000

4000

0

and

Traffic non exhaust
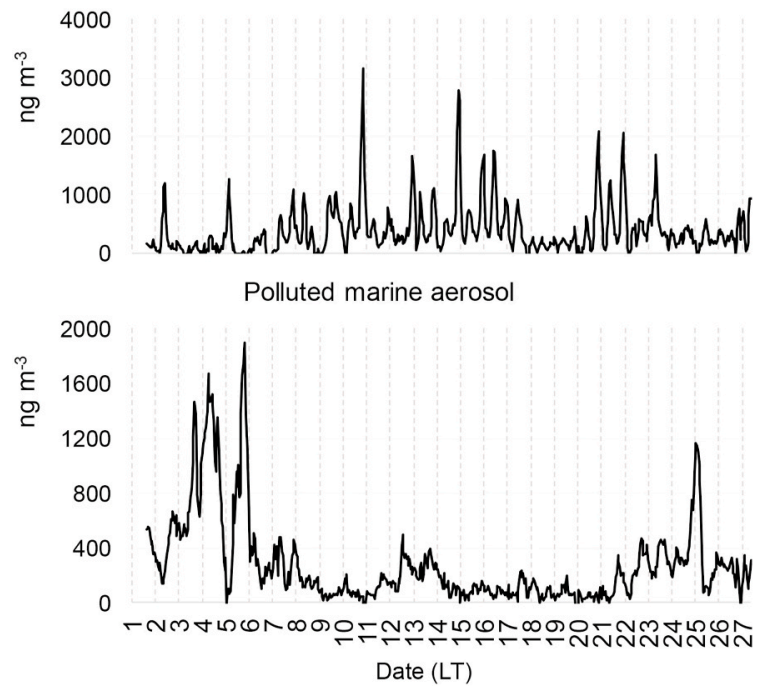

Nitrate and aged aerosol

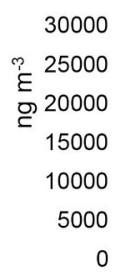

0

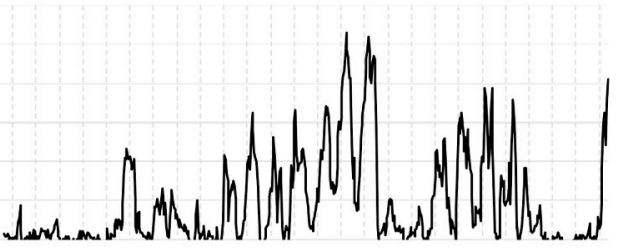

Sulphate

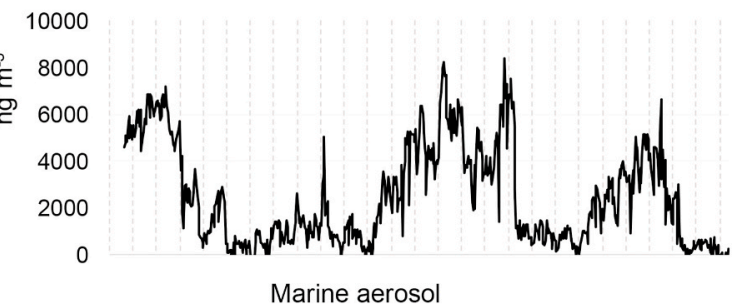

20000

$\stackrel{?}{\varepsilon} 16000$

오 12000

8000

4000

0

$d$

arine aerosol

12000

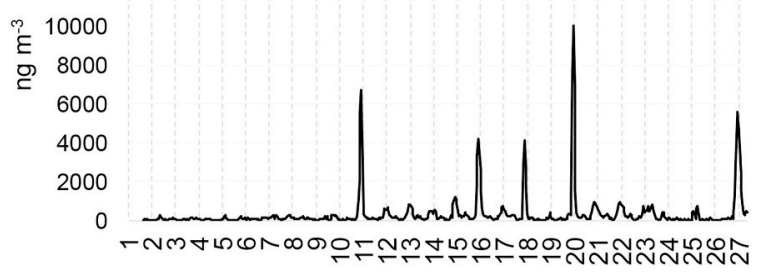

Date (LT)

Fig. 2. Hourly temporal patterns of the nine-factor constrained solution for February 2017. Vertical lines show midnight in each day.

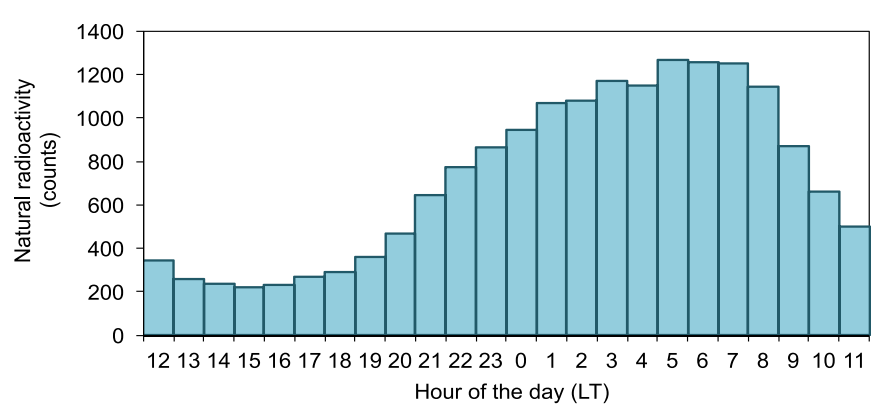

Fig. 3. Mean diurnal cycle of natural radioactivity during the CARE campaign. the average over the whole campaign (see Fig. 2) - the source retrieved by the model probably included minor contributions also from local soil resuspension. The mass contribution of this source over the whole campaign was $3.8 \%$, but during the mineral dust advection it accounted for a relevant fraction ( $49 \%$ on average) of the $\mathrm{PM}_{2.5}$ mass concentration.

Factor 6 was identified as a marine aerosol source being characterised by $\mathrm{EVF}=0.89$ for $\mathrm{Cl}$, with the second highest EVF being 0.27 for $\mathrm{Na}$. Typical diagnostic ratios for this source, i.e. $\mathrm{Mg} / \mathrm{Na}$ and $\mathrm{Cl} / \mathrm{Na}$, were respectively 0.13 and 1.9 , very similar to what expected for bulk sea salt aerosol (0.12 and 1.8, respectively) (Seinfeld and Pandis, 2006). It is noteworthy that local atmospheric circulation for the area under investigation allows the inland penetration of weak sea breezes, even if Rome is about $30 \mathrm{~km}$ from the nearest sea cost. This episodic source contributed on average for about $3.6 \%$ of the total $\mathrm{PM}_{2.5}$ mass, up to $47 \%$ on average during the advection (Fig. 2). 
Factor 7 was assigned to traffic non-exhaust emissions (including road dust resuspension), since high EVF were associated to main tracers for this source: $\mathrm{Ca}(0.57), \mathrm{Zn}(0.38), \mathrm{Fe}(0.34)$, Mn (0.42), and $\mathrm{Cr}(0.45)$ (Thorpe and Harrison, 2008; Jeong et al., 2019). EVF for Cu was a bit lower (0.20), because this element was found with higher concentrations (11.8 $\mathrm{ng} \mathrm{m}^{-3}$ compared to $2.5 \mathrm{ng} \mathrm{m}^{-3}$ ) in the chemical profile of a factor that was associated to local emissions (see afterwards). Connection with traffic emissions was also confirmed by the presence of EC in the chemical profile (14\%), likely due to road dust resuspension. The average contribution of traffic non-exhaust emissions to $\mathrm{PM}_{2.5}$ over the CARE campaign was quite low $(2.2 \%)$, as already found for same fraction by e.g. Amato et al. (2016).

Factor 8 showed a strong episodic character (see Fig. 2) and presented a high EVF for $\mathrm{Cu}(0.78)$ and $\mathrm{Pb}(0.61)$. The high EC contribution in the chemical profile was likely associated to combustion emissions and the optical absorption profile of this factor (see Sect. 3.2) suggested an influence of fossil fuel combustion $(\alpha \approx 1)$. This is the first time that a similar factor has been detected in the urban area of Rome and - as far as we know - it was not reported in previous literature works; therefore, this factor was tentatively assigned to local emissions but further investigation is needed in the future to identify the specific source. The local feature of the source is evidenced in Fig. $5 \mathrm{~S}$ in the Supplement realised through the open air R package (Carslaw and Ropkins, 2012; Carslaw, 2019) - which shows variation in source contributions by wind speed and wind direction. The episodic and late evening contribution of this source (Fig. 2) is also likely influenced by boundary layer dynamics (Fig. 3). The average mass contribution of this source was very low (1.9\%).

Factor 9 was associated with polluted marine aerosol. Indeed, main tracers of aged sea salt aerosol are $\mathrm{Na}$ and $\mathrm{Mg}$ which showed EVF values of 0.67 and 0.34 , respectively; moreover, EVF for V (0.41) and $\mathrm{Ni}(0.26)$ were also of interest as they are elemental markers for heavy oil combustion here likely related to ship emissions, as already highlighted by Valentini et al. (2020) for the CARE campaign. Mg-to-Na ratio in the chemical profile was 0.14 (i.e. in fair agreement with 0.12 reported in the literature) and the chemical profile did not contain $\mathrm{Cl}$; opposite, the chemical profile was clearly enriched in $\mathrm{SO}_{4}^{2-}$ and $\mathrm{NO}_{3}^{-}$, highlighting the ageing of sea salt aerosol (Seinfeld and Pandis, 2006). Moreover, the presence of EC in the profile suggested the influence of ship emissions and the contamination due to air mass transport from the coast. The average mass contribution of this source was $1.6 \%$ at the receptor site.

A bootstrap analysis with 100 convergent runs was performed to evaluate the uncertainties associated with source profiles (Crespi et al., 2016); results are shown in Fig. 4. Main tracers of each source were characterised by small interquartile ranges (blue bars, with values expressed in $\mathrm{ng} \mathrm{m}^{-3}$ or $\mathrm{Mm}^{-1}$ on a logarithmic scale). Mapping of factors was always $99 \%$, supporting the goodness of the solution presented in this work.

\subsection{Model results exploiting optical variables}

As mentioned in the previous section, the source apportionment of the light absorption coefficients at different wavelengths (see Fig. 1b) strengthens the identification of sources giving additional information about their contribution to light absorption in the atmosphere. In addition, the multi-variable modelling approach introduced by Forello et al. (2019) allows the retrieval of relevant source-dependent optical parameters - such as the absorption Ångström exponent and the mass absorption cross section - without any a-priori assumption.

In Table 2 the $b_{\text {ap }}$ apportionment at different wavelengths is shown; traffic exhaust and local source emissions are added together to consider total fossil fuel emissions.

As expected, the relative contribution to the total reconstructed $b_{a p}$ ascribed to the factors related to biomass burning and mineral dust decreases with increasing $\lambda$, in contrast to the contribution from fossil fuel combustion. The most significant contribution to $b_{a p}$ at all wavelengths is given by the traffic exhaust emission source (significant also in terms of EVF, ranging from 0.63 to 0.77 and increasing with increasing wavelength), followed by the factor assigned to the local source. These two main contributors to optical absorption in the atmosphere are related to fossil fuel combustion (traffic exhaust + local source emissions) as highlighted by the value of the absorption Ångström exponent $(\alpha)$ that is 1.1 (1.0-1.1 as 10 th - 90th percentile from the bootstrap analysis); in fact, $\alpha$ values near 1 are typically associated to light absorption contribution dominated by fresh black carbon (BC) emissions. In Fig. 5a, the wavelength dependence of $b_{a p}$ for fossil fuel emissions is reported; the line corresponds to the data fitting considering $\mathrm{b}_{\mathrm{ap}} \propto \lambda^{-\alpha}$.

Even if the other sources do not contribute as much as fossil fuel emissions to the absorption in the atmosphere, useful information can be retrieved considering source-dependent optical parameters.

The wavelength dependence of $b_{a p}$ apportioned to the biomass burning source is reported in Fig. $5 \mathrm{~b}$ where the $\alpha$ value from the fitting is 4.4 (4.4-4.5 as 10th - 90th percentile); it is higher than typical literature $\alpha$ values for biomass burning (e.g. Sandradewi et al., 2008; and references therein) but the significant role played by brown carbon (BrC, i.e. light absorbing organic carbon) in this source can account for it (Laskin et al., 2015). In the literature, BrC was already found in particles enriched in nitrate (that is the second highest contributor in the source chemical profile, after $\mathrm{OA}$ ) and poor in BC, with a BC-to-OA ratio below $0.05 \pm 0.03$ (Costabile et al., 2017b); considering EC as a proxy for BC, the ratio in the biomass burning chemical profile was 0.02 .

The wavelength dependence of $b_{\text {ap }}$ for the nitrate and aged aerosol source is reported in Fig. 5c; $\alpha$ value is 2.1 (1.6-2.6 as 10th - 90th percentile from bootstrap analysis), consistent with a mixed contribution from both BC and BrC.

Even if the mineral dust source is characterised by very low values of $b_{a p}$ it has a clear wavelength dependence (Fig. 5d), in contrast to the other remaining sources giving negligible contributions to light absorption. For this source, $\alpha$ is 2.9 (2.6-3.5 as 10 th - 90th percentile), i.e. comprehended in the typical range for desert dust reported in the literature (e.g. Caponi et al., 2017; and references therein). This result is noteworthy because values for the absorption Ångström exponent of mineral dust are still relatively scarce in the literature.

Absolute $b_{a p}$ values apportioned in the mineral dust source are much lower (ranging from $0.9 \%$ to $0.3 \%$ of the total reconstructed $b_{a p}$ depending on the wavelength - see Table 2) than the ones from fossil fuels combustion and biomass burning; this result can be expected since the transport episode of mineral dust is very short (lasting less than two days over the whole campaign). The picture is totally different when considering the time interval covering the transport event (from 24th February 12:00 until 25th February 15:00 LT, estimated considering the temporal pattern in Fig. 2); indeed, even if the dominant contribution is still given by fossil fuels combustion (from 59\% to $75 \%$ of the total reconstructed $b_{a p}$, increasing with increasing wavelength), the mineral dust impact on light absorption ranges from $25 \%$ at $\lambda=370 \mathrm{~nm}$ to $10 \%$ at $\lambda=950 \mathrm{~nm}$.

Another relevant result from this modelling approach is the estimate of the ratio between $b_{a p}(\lambda)$ and $E C$ - here considered as a proxy for BC concentrations - for each source. It is noteworthy that when $\mathrm{BC}$ is the only absorbing component, $\mathrm{b}_{\mathrm{ap}}(\lambda)$-to-EC ratio provides the mass $\mathrm{ab}$ sorption cross-section of $\mathrm{BC}\left(\mathrm{MAC}_{\mathrm{BC}}\right)$ at different wavelengths; this assumption can be considered valid for fossil fuel emissions (for which $\alpha$ $=1.1$ ).

Calculations of $\mathrm{b}_{\mathrm{ap}}(\lambda) / \mathrm{EC}$ for biomass burning, fossil fuel, and nitrate and aged aerosol sources are reported in Fig. 6 and Table $2 S$ in the Supplement.

In the case of the fossil fuel emissions source during the CARE campaign, $\mathrm{MAC}_{\mathrm{BC}}(\lambda)$ resulted to be: 18.3 (17.6-18.6 as 10 th -90 th percentile from the bootstrap analysis) $\mathrm{m}^{2} \mathrm{~g}^{-1}$ at $\lambda=370 \mathrm{~nm} ; 14.5$ (13.9-14.7) $\mathrm{m}^{2} \mathrm{~g}^{-1}$ at $\lambda=470 \mathrm{~nm} ; 12.7(12.2-12.9) \mathrm{m}^{2} \mathrm{~g}^{-1}$ at $\lambda=520$ $\mathrm{nm} ; 11.1(10.7-11.3) \mathrm{m}^{2} \mathrm{~g}^{-1}$ at $\lambda=590 \mathrm{~nm} ; 9.7(9.3-9.9) \mathrm{m}^{2} \mathrm{~g}^{-1}$ at $\lambda=$ 

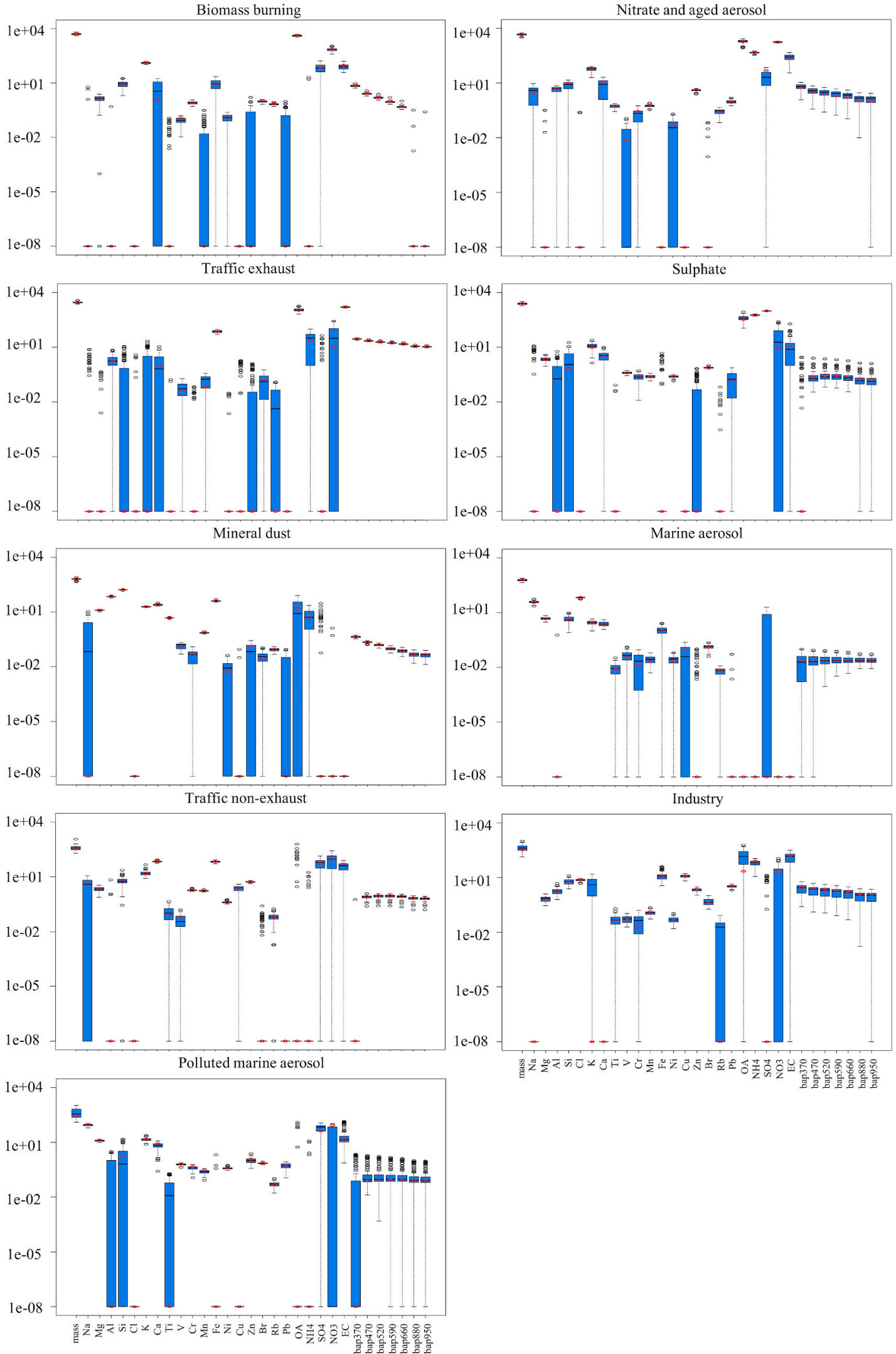

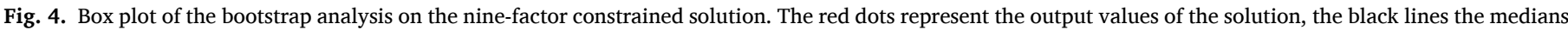

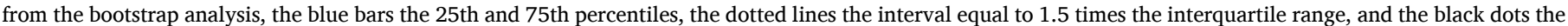
outliers from this interval. (For interpretation of the references to colour in this figure legend, the reader is referred to the Web version of this article.) 
Table 2

Average contribution to total reconstructed $b_{a p}$; in parentheses, the 10th and 90th percentiles are reported.

\begin{tabular}{|c|c|c|c|c|c|c|c|}
\hline & $370 \mathrm{~nm}$ & $470 \mathrm{~nm}$ & $520 \mathrm{~nm}$ & $590 \mathrm{~nm}$ & $660 \mathrm{~nm}$ & $880 \mathrm{~nm}$ & $950 \mathrm{~nm}$ \\
\hline Biomass burning & $\begin{array}{l}17 \% \\
(14-18)\end{array}$ & $\begin{array}{l}8.5 \% \\
(6.8-9.0)\end{array}$ & $\begin{array}{l}6.0 \% \\
(4.9-6.4)\end{array}$ & $\begin{array}{l}4.1 \% \\
(3.4-4.4)\end{array}$ & $\begin{array}{l}2.5 \% \\
(2.0-2.7)\end{array}$ & $\begin{array}{l}0 \% \\
(0-0)\end{array}$ & $\begin{array}{l}0 \% \\
(0-0)\end{array}$ \\
\hline Nitrate and aged aerosol & $\begin{array}{l}12 \% \\
(8.9-22)\end{array}$ & $\begin{array}{l}9.2 \% \\
(5.9-19)\end{array}$ & $\begin{array}{l}8.5 \% \\
(5.2-18)\end{array}$ & $\begin{array}{l}8.1 \% \\
(4.6-18)\end{array}$ & $\begin{array}{l}7.8 \% \\
(4.3-17)\end{array}$ & $\begin{array}{l}7.1 \% \\
(3.6-17)\end{array}$ & $\begin{array}{l}6.9 \% \\
(3.4-17)\end{array}$ \\
\hline Mineral dust & $\begin{array}{l}0.9 \% \\
(0.8-1.1)\end{array}$ & $\begin{array}{l}0.7 \% \\
(0.6-0.8)\end{array}$ & $\begin{array}{l}0.6 \% \\
(0.5-0.6)\end{array}$ & $\begin{array}{l}0.4 \% \\
(0.3-0.5)\end{array}$ & $\begin{array}{l}0.4 \% \\
(0.2-0.4)\end{array}$ & $\begin{array}{l}0.3 \% \\
(0.2-0.4)\end{array}$ & $\begin{array}{l}0.3 \% \\
(0.2-0.4)\end{array}$ \\
\hline Fossil fuel & $\begin{array}{l}70 \% \\
(62-73)\end{array}$ & $\begin{array}{l}78 \% \\
(69-81)\end{array}$ & $\begin{array}{l}80 \% \\
(71-83)\end{array}$ & $\begin{array}{l}82 \% \\
(72-84)\end{array}$ & $\begin{array}{l}83 \% \\
(73-86)\end{array}$ & $\begin{array}{l}86 \% \\
(75-89)\end{array}$ & $\begin{array}{l}86 \% \\
(76-89)\end{array}$ \\
\hline
\end{tabular}

(a)

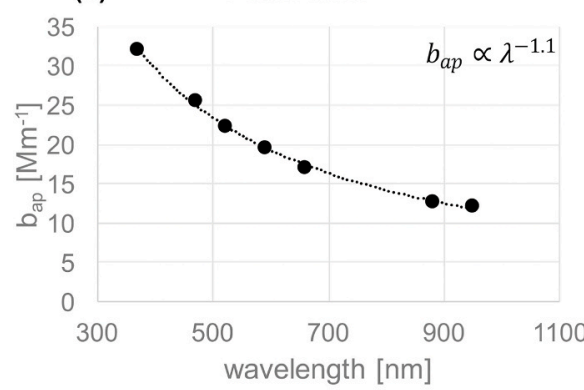

(c) Nitrate and aged aerosol

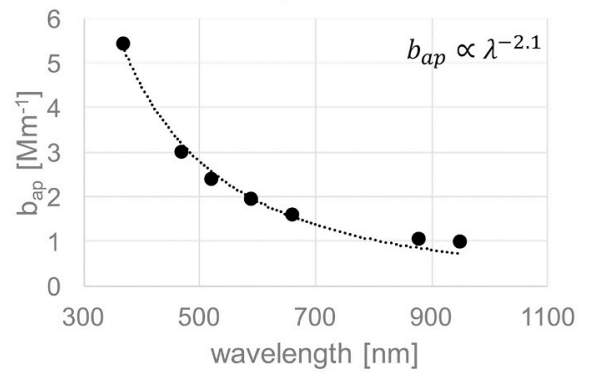

(b) Biomass burning (rich in $\mathrm{BrC}$ )

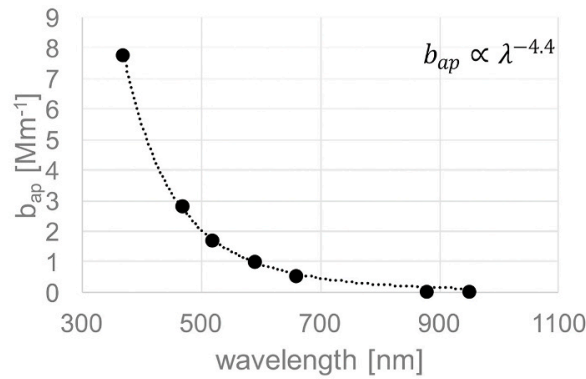

(d) Mineral dust

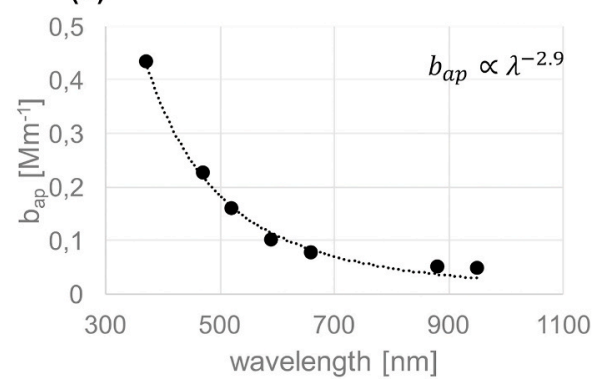

Fig. 5. $b_{\text {ap }}$ dependence on $\lambda$ for (a) fossil fuels, (b) biomass burning, (c) nitrate and aged aerosol, and (d) mineral dust.

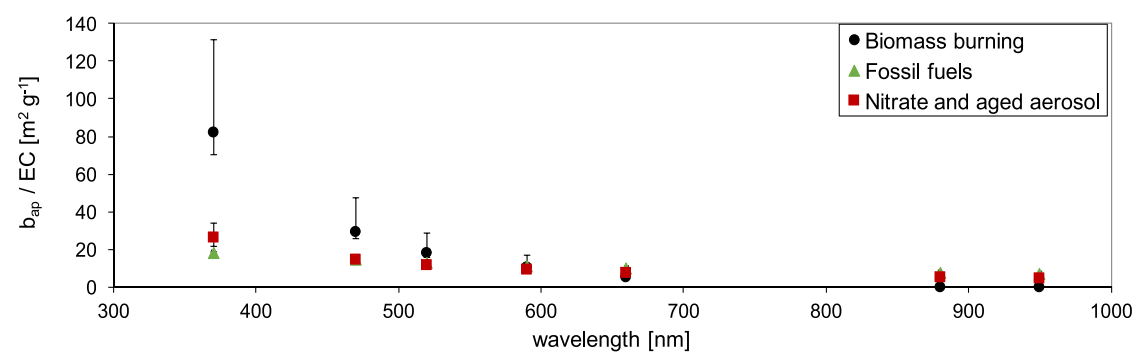

Fig. 6. $b_{\text {ap }}$-to-EC ratio dependence on $\lambda$ for biomass burning, fossil fuels, and nitrate and aged aerosol. Error bars represent the 10th and 90th percentiles from the bootstrap analysis.

$660 \mathrm{~nm} ; 7.2(6.9-7.4) \mathrm{m}^{2} \mathrm{~g}^{-1}$ at $\lambda=880 \mathrm{~nm} ; 6.9(6.6-7.0) \mathrm{m}^{2} \mathrm{~g}^{-1}$ at $\lambda=$ $950 \mathrm{~nm}$ (Table $2 \mathrm{~S}$ in the Supplement). The average MAC value for BC not related to the specific sources - was estimated by Costabile et al. (2017a) during the same campaign as $8.7 \mathrm{~m}^{2} \mathrm{~g}^{-1}$ at $\lambda=637 \mathrm{~nm}$.

It is noteworthy the large difference at shorter wavelengths among the various sources, which is due to the contribution of BrC. The difference is clearly more significant for biomass burning, where $\mathrm{BrC}$ resulted to be dominant ( $\alpha=4.4$ ), while significant differences in the nitrate and aged aerosol are present only at $\lambda=370 \mathrm{~nm}$ ( $\alpha$ for this source was 2.1) compared to fossil fuels.

\subsection{Comparison between ME-2 modelling and ACSM results on organics}

In order to obtain more insights on the OA apportionment, results from the modelling approach presented in this work coupling chemical and optical variables (ME- $2_{\text {all }}$, in the following) were compared with an independent source apportionment study previously performed on the organic fraction OA measured by the ACSM (ME-2 ${ }_{\text {org }}$, in the following) (see paragraph 2.2.3). Using the latter approach, three factors were recognised: HOA (hydrocarbon-like organic aerosol), BBOA (biomass burning-like organic aerosol), and OOA (oxygenated organic aerosol); HOA and BBOA (i.e. primary OA components) accounted for about $12 \%$ of the OA mass each, while OOA was the main component accounting 
for the remaining apportioned mass fraction.

Results from the application of ME- $2_{\text {all }}$ showed that the main contributors to organic aerosol concentrations in the atmosphere (see also Fig. 1a) were biomass burning (accounting nearly for $58 \%$ of the total OA concentrations reconstructed by the model), nitrate and aged aerosol (almost 24\%), and traffic exhaust emissions (almost 14\%).

As an original contribution of this work, in Fig. 7 a comparison between temporal patterns related to OA apportioned by ME- 2 all (hereafter

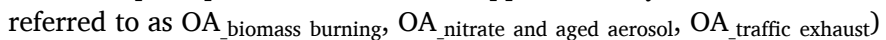
vs. $\mathrm{BBOA}, \mathrm{OOA}$, and $\mathrm{HOA}$ obtained by $\mathrm{ME}-2_{\text {org }}$ is reported.

The first noteworthy result is that HOA and $\mathrm{OA}_{\text {_traffic }}$ exhaust retrieved by the two different approaches are similar in temporal patterns $\left(\mathrm{R}^{2}=\right.$ 0.85 ) but - more importantly - fairly comparable in terms of absolute values (within $10 \%$ difference on average) (Fig. 7a).

Also OA_nitrate and aged aerosol shows similar features to OOA $\left(\mathrm{R}^{2}=\right.$ 0.74 ) in terms of temporal behaviour thus confirming that secondary aerosol and ageing processes impact on the source identified by ME- 2 all as nitrate and aged aerosol. Correlation between the fraction of semivolatile OOA (SV-OOA) and $\mathrm{NO}_{3}^{-}$was already observed in Rome (Struckmeier et al., 2016), in agreement with other literature studies (DeCarlo et al., 2010). OA_nitrate and aged aerosol absolute values are much lower than OOA from ME- $2_{\text {org }}$ (Fig. $7 \mathrm{~b}$ ), suggesting that part of the OOA is apportioned to other sources by ME- 2 all.

The biomass burning source retrieved by ME- 2 all is characterised by a more complex mixture of organics showing a significant correlation with both BBOA $\left(\mathrm{R}^{2}=0.74\right)$ and OOA $\left(\mathrm{R}^{2}=0.75\right)$ from ME- $2_{\text {org }}$. However, one relevant difference is related to $\mathrm{BBOA}$ absolute concentration values, which do not account for all the OA apportioned by ME- $2_{\text {all }}$ to the biomass burning source. In addition, the decrease of BBOA concentration values steeply reaches zero (typically during the time interval from 11 to $17 \mathrm{LT}$ ) while the $\mathrm{OA}_{\text {biomass burning has higher concentration values }}$ (Fig. 7c), especially during the period characterised by atmospheric stability (from about 10/02 until 24/02, excluding 18/02 and 19/02).

The discrepancies in organic aerosol absolute values mentioned for the latter two cases are very interesting and deserve a further discussion as they were never reported in previous works. Indeed, this observation can be explained considering that a consistent part of the OOA generically ascribed to aged aerosol in literature works (see e.g. DeCarlo et al., 2010) - is likely linked to the biomass burning source as shown by ME- $2_{\text {all }}$ results and better described in the following. As can be seen in Fig. 8, the temporal pattern of the difference between $\mathrm{OA}_{\text {biomass burning }}$ and $\mathrm{BBOA}$ is substantially overlapped with the difference between OOA from ME- $2_{\text {org }}$ and $\mathrm{OA}_{\text {nitrate }}$ and aged aerosol from ME- $2_{\text {all }}$ (in the following, OOA-OA_nitrate and aged aerosol). Consistently, adding the contribution from OOA-OA_nitrate and aged aerosol to BBOA apportioned by ME- $2_{\text {org }}$, the correlation with the biomass burning source from ME- $2_{\text {all }}$ significantly increases $\left(\mathrm{R}^{2}=0.92\right.$ vs. 0.74$)$ and also absolute concentration values are very similar, within $4 \%$ on average. Therefore, OOA-OA_nitrate and aged aerosol can be considered a rough minimum estimation of the biomass burning contribution to OOA and on average it accounts for $60 \%$ of OOA concentrations, corresponding to $43 \%$ of total OA measured by ACSM.

This is the second noteworthy result of this work, as it represents an estimate of the secondary contribution to OA due to biomass burning; therefore, it could be added to the $12 \%$ estimated as BBOA (typically associated only to primary aerosol content), evidencing the eminent role of biomass burning ( $>50 \%$ ) - with its primary and secondary contributions - in explaining the total OA measured during the CARE campaign.

In contrast to the other two sources, the chemical profile of traffic exhaust from ME- $2_{\text {all }}$ seems to be constituted mainly by primary emissions since $\mathrm{OA}_{\text {-traffic exhaust }}$ from ME- $2_{\text {all }}$ corresponds to HOA from ME$2_{\text {org: }}$ thus, OOA contributions related to secondary organic components can be considered negligible in this source. Secondary organic compounds due to traffic emissions are likely mixed in the chemical profile of the nitrate and aged aerosol source from ME- $2_{\text {all, }}$ so that minimum
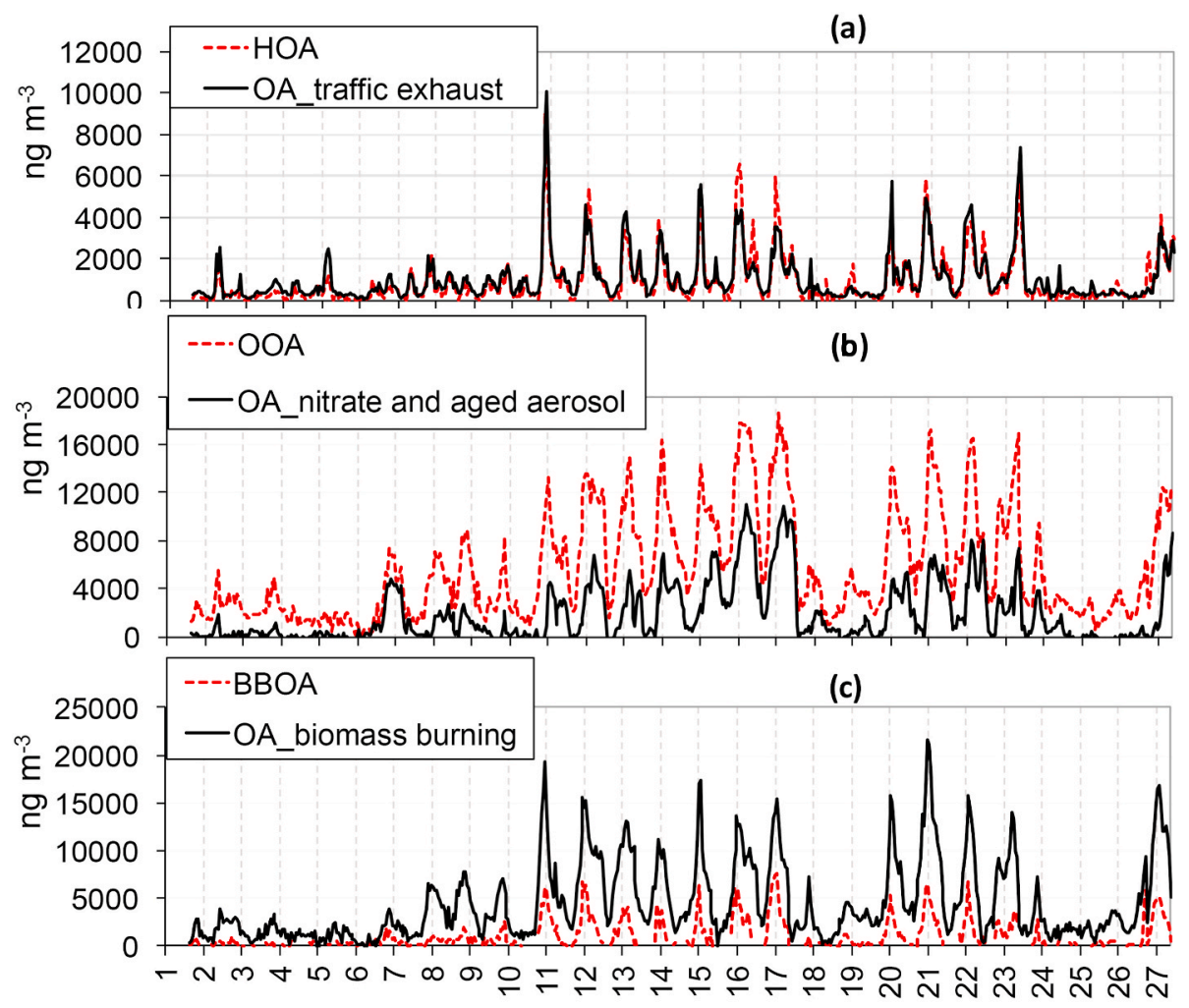

Date (LT)

Fig. 7. Hourly temporal patterns of (a) HOA from ME- $2_{\text {org }}$ and OA apportioned to traffic exhaust by ME- $2_{\text {all }}$, (b) OOA from ME- $2_{\text {org }}$ and OA apportioned to nitrate and aged aerosol by ME- $2_{\text {all }}$, (c) BBOA from ME- $2_{\text {org }}$ and OA apportioned to biomass burning by ME- 2 all for February 2017 . Vertical lines show midnight for each day. 


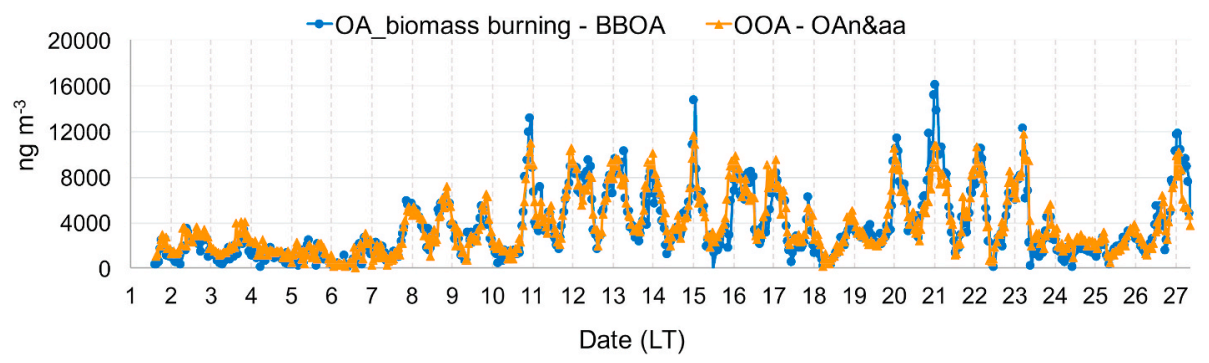

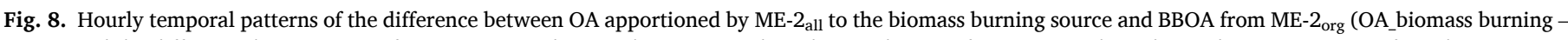

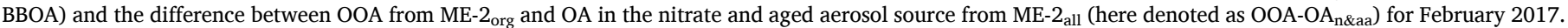
Vertical lines show midnight for each day.

estimation of their contribution is not possible in this case.

\section{Conclusions}

In this work, the multi-time ME-2 was applied to a multi-variable dataset comprising high-time resolution chemical and optical variables collected at an urban site impacted by episodic sources. The peculiar aerosol characteristics - which were heavily influenced by both anthropogenic and natural sources - together with the availability of information about organic aerosol apportionment retrieved by ACSM, made it possible to further test the robustness of the approach recently introduced by Forello et al. (2019) and to show new potentialities.

A noteworthy result of this work is the possibility to gain knowledge on the OA source apportionment and to relate primary and secondary OA contributions to their emission sources; at the state of the art, this is still an important area of investigation in receptor modelling. In particular, biomass burning was estimated to contribute to OA for about $55 \%$ and the biomass burning secondary contribution (typically accounted for in OOA by literature works dealing with ACSM data) was found to be dominant respect to the primary one $(12 \%)$, i.e. the one included in the BBOA component given by ACSM.

The added value of the insertion of the optical variables in the modelling procedure presented in this work is the assessment of optical absorption contribution from mineral dust. Its contribution was relevant (impacting on $\mathrm{b}_{\mathrm{ap}}(\lambda)$ apportionment from $25 \%$ to $10 \%$, decreasing with increasing wavelength) when a not negligible mineral dust transport episode was registered at the measurement site. In addition, sourcedependent optical absorption parameters (e.g. the absorption Ångström exponent, $\alpha$ ) were retrieved for fossil fuel and biomass burning emission sources as well as for mineral dust as output of the receptor model. The latter result can be of great interest e.g. for the Aethalometer model users as a-priori assumptions on the absorption Ångström exponent are still causing the large part of the uncertainties associated to the optical apportionment models results (Zotter et al., 2017).

In perspective, our modelling approach paves the way to more powerful receptor models which have the potential of providing much more insights on aerosol properties and sources.

\section{Data availability}

For any request, please contact Roberta Vecchi (roberta.vecchi@uni mi.it).

\section{CRediT authorship contribution statement}

A.C. Forello: Conceptualization, Methodology, Validation, Formal analysis, Writing - original draft, Writing - review \& editing, Visualization. F. Amato: Investigation, Data curation, Writing - review \& editing. V. Bernardoni: Validation, Writing - review \& editing. G. Calzolai: Investigation, Data curation, Writing - review \& editing. S. Canepari: Investigation, Data curation, Writing - review \& editing. F. Costabile:
Investigation, Data curation, Writing - review \& editing. L. Di Liberto: Investigation, Data curation, Writing - review \& editing. M. Gualtieri: Investigation, Data curation, Writing - review \& editing. F. Lucarelli: Investigation, Data curation, Writing - review \& editing. S. Nava: Investigation, Data curation, Writing - review \& editing. C. Perrino: Investigation, Data curation, Writing - review \& editing. E. Petralia: Investigation, Data curation, Writing - review \& editing. S. Valentini: Validation, Investigation, Writing - review \& editing. G. Valli: Conceptualization, Validation, Writing - review \& editing. R. Vecchi: Conceptualization, Validation, Writing - review \& editing, Supervision.

\section{Declaration of competing interest}

The authors declare that they have no known competing financial interests or personal relationships that could have appeared to influence the work reported in this paper.

\section{Acknowledgements}

The CARE experiment was realised under the patronage of the Councilor for environmental sustainability of Roma Capitale. The authors are grateful to all members of the research groups who participated to the CARE experiment.

\section{Appendix A. Supplementary data}

Supplementary data to this article can be found online at https://doi. org/10.1016/j.atmosenv.2020.117873.

\section{Funding}

This research did not receive any specific grant from funding agencies in the public, commercial, or not-for-profit sectors.

\section{References}

Alas, H.D.C., Weinhold, K., Costabile, F., Di Ianni, A., Müller, T., Pfeifer, S., Di Liberto, L., Turner, J.R., Wiedensohler, A., 2019. Methodology for high-quality mobile measurement with focus on black carbon and particle mass concentrations. Atmos. Meas. Tech 12, 4697-4712. https://doi.org/10.5194/amt-12-4697-2019.

Amato, F., Alastuey, A., Karanasiou, A., Lucarelli, F., Nava, S., Calzolai, G., Severi, M., Becagli, S., Gianelle, V.L., Colombi, C., Alves, C., Custódio, D., Nunes, T., Cerqueira, M., Pio, C., Eleftheriadis, K., Diapouli, E., Reche, C., Minguillón, M.C., Manousakas, M.-I., Maggos, T., Vratolis, S., Harrison, R.M., Querol, X., 2016. AIRUSE-LIFE+: a harmonized PM speciation and source apportionment in five southern European cities. Atmos. Chem. Phys. 16, 3289-3309. https://doi.org/ 10.5194/acp-16-3289-2016.

Belis, C.A., Favez, O., Mircea, M., Diapouli, E., Manousakas, M.-I., Vratolis, S., Gilardoni, S., Paglione, M., Decesari, S., Mocnik, G., Mooibroek, D., Salvador, P., Takahama, S., Vecchi, R., Paatero, P., 2019a. European Guide on Air Pollution Source Apportionment with Receptor Models - Revised Version 2019. Publications Office of the European Union, Luxembourg. https://doi.org/10.2760/439106.

Belis, C.A., Pikridas, M., Lucarelli, F., Petralia, E., Cavalli, F., Calzolai, G., Berico, M., Sciare, J., 2019b. Source apportionment of fine PM by combining high time resolution organic and inorganic chemical composition datasets, Atmos. Environ. Times X 3, 100046. https://doi.org/10.1016/j.aeaoa.2019.100046. 
Brown, S.G., Eberly, S., Paatero, P., Norris, G.A., 2015. Methods for estimating uncertainty in PMF solutions: examples with ambient air and water quality data and guidance on reporting PMF results. Sci. Total Environ. 518-519. https://doi.org/ 10.1016/j.scitotenv.2015.01.022, 626-635.

Calzolai, G., Lucarelli, F., Chiari, M., Nava, S., Giannoni, M., Carraresi, L., Prati, P., Vecchi, R., 2015. Improvements in PIXE analysis of hourly particulate matter samples. Nucl. Instrum. Methods B 363, 99-104. https://doi.org/10.1016/j. nimb.2015.08.022.

Canagaratna, M.R., Jayne, J.T., Jimenez, J.L., Allan, J.D., Alfarra, M.R., Zhang, Q., Onasch, T.B., Drewnick, F., Coe, H., Middlebrook, A., Delia, A., Williams, L.R., Trimborn, A.M., Northway, M.J., DeCarlo, P.F., Kolb, C.E., Davidovits, P., Worsnop, D.R., 2007. Chemical and microphysical characterization of ambient aerosols with the aerodyne aerosol mass spectrometer. Mass Spectrom. Rev. 26, 185-222. https://doi.org/10.1002/mas.20115.

Canonaco, F., Crippa, M., Slowik, J.G., Baltensperger, U., Prévôt, A.S.H., 2013. SoFi, an IGOR-based interface for the efficient use of the generalized multilinear engine (ME2) for the source apportionment: ME-2 application to aerosol mass spectrometer data. Atmos. Meas. Tech. 6, 3649-3661. https://doi.org/10.5194/amt-6-3649-2013.

Caponi, L., Formenti, P., Massabò, D., Di Biagio, C., Cazaunau, M., Pangui, E., Chevaillier, S., Landrot, G., Andreae, M.O., Kandler, K., Piketh, S., Saeed, T. Seibert, D., Williams, E., Balkanski, Y., Prati, P., Doussin, J.-F., 2017. Spectral- and size-resolved mass absorption efficiency of mineral dust aerosols in the shortwave spectrum: a simulation chamber study. Atmos. Chem. Phys. 17, 7175-7191. https:// doi.org/10.5194/acp-17-7175-2017.

Carslaw, D.C., Ropkins, K., 2012. Openair - an R package for air quality data analysis. Environ. Model. Software 27-28, 52-61. https://doi.org/10.1016/j. envsoft.2011.09.008.

Carslaw, D.C., 2019. The Openair Manual - Open-Source Tools for Analysing Air Pollution Data. In: Manual for Version 2.6-6. University of York.

Costabile, F., Alas, H., Aufderheide, M., Avino, P., Amato, F., Argentini, S., Barnaba, F., Berico, M., Bernardoni, V., Biondi, R., Calzolai, G., Canepari, S., Casasanta, G., Ciampichetti, S., Conidi, A., Cordelli, E., Di Ianni, A., Di Liberto, L., Facchini, M.C., Facci, A., Frasca, D., Gilardoni, S., Grollino, M.G., Gualtieri, M., Lucarelli, F., Malaguti, A., Manigrasso, M., Montagnoli, M., Nava, S., Padoan, E., Perrino, C., Petralia, E., Petenko, I., Querol, X., Simonetti, G., Tranfo, G., Ubertini, S., Valli, G., Valentini, S., Vecchi, R., Volpi, F., Weinhold, K., Wiedensohler, A., Zanini, G., Gobbi, G.P., 2017a. First results of the "carbonaceous aerosol in Rome and Environ (CARE)" experiment: beyond current standards for $\mathrm{PM}_{10}$. Atmosphere 8 (12), 249. https://doi.org/10.3390/atmos8120249.

Costabile, F., Gilardoni, S., Barnaba, F., Di Ianni, A., Di Liberto, L., Dionisi, D. Manigrasso, M., Paglione, M., Poluzzi, V., Rinaldi, M., Facchini, M.C., Gobbi, G.P., 2017b. Characteristics of brown carbon in the urban Po Valley atmosphere. Atmos. Chem. Phys. 17, 313-326. https://doi.org/10.5194/acp-17-313-2017.

Costabile, F., Gualtieri, M., Canepari, S., Tranfo, G., Consales, C., Grollino, M.G., Paci, E., Petralia, E., Pigini, D., Simonetti, G., 2019. Evidence of association between aerosol properties and in-vitro cellular oxidative response to $\mathrm{PM}_{1}$, oxidative potential of $\mathrm{PM}_{2.5}$, a biomarker of RNA oxidation, and its dependency on combustion sources. Atmos. Environ. 213, 444-455. https://doi.org/10.1016/j.atmosenv.2019.06.023.

Crenn, V., Sciare, J., Croteau, P.L., Verlhac, S., Fröhlich, R., Belis, C.A., Aas, W., Äijälä, M., Alastuey, A., Artiñano, B., Baisnée, D., Bonnaire, N., Bressi, M., Canagaratna, M., Canonaco, F., Carbone, C., Cavalli, F., Coz, E., Cubison, M.J., EsserGietl, J.K., Green, D.C., Gros, V., Heikkinen, L., Herrmann, H., Lunder, C., Minguillón, M.C., Močnik, G., O’Dowd, C.D., Ovadnevaite, J., Petit, J.E., Petralia, E., Poulain, L., Priestman, M., Riffault, V., Ripoll, A., Sarda-Estève, R., Slowik, J.G., Setyan, A., Wiedensohler, A., Baltensperger, U., Prévôt, A.S.H., Jayne, J.T., Favez, O., 2015. ACTRIS ACSM intercomparison - Part 1: reproducibility of concentration and fragment results from 13 individual Quadrupole Aerosol Chemical Speciation Monitors (Q-ACSM) and consistency with co-located instruments Atmos. Meas. Tech. 8 (12), 5063-5087. https://doi.org/10.5194/amt-8-5063-2015.

Crespi, A., Bernardoni, V., Calzolai, G., Lucarelli, F., Nava, S., Valli, G., Vecchi, R., 2016 Implementing constrained multi-time approach with bootstrap analysis in ME-2: an application to PM2.5 data from Florence (Italy). Sci. Total Environ. 541, 502-511. https://doi.org/10.1016/j.scitotenv.2015.08.159.

D’Alessandro, A., Lucarelli, F., Mandò, P.A., Marcazzan, G., Nava, S., Prati, P., Valli, G., Vecchi, R., Zucchiatti, A., 2003. Hourly elemental composition and sources identification of fine and coarse PM10 particulate matter in four Italian towns. J. Aerosol Sci. 34, 243-259. https://doi.org/10.1016/S0021-8502(02)00172-6.

DeCarlo, P.F., Ulbrich, I.M., Crounse, J., de Foy, B., Dunlea, E.J., Aiken, A.C., Knapp, D., Weinheimer, A.J., Campos, T., Wennberg, P.O., Jimenez, J.L., 2010. Investigation of the sources and processing of organic aerosol over the Central Mexican Plateau from aircraft measurements during MILAGRO. Atmos. Chem. Phys. 10, 5257-5280. https://doi.org/10.5194/acp-10-5257-2010.

Drinovec, L., Močnik, G., Zotter, P., Prévôt, A.S.H., Ruckstuhl, C., Coz, E., Rupakheti, M. Sciare, J., Müller, T., Wiedensohler, E., Hansen, D.A., 2015. The "dual-spot" Aethalometer: an improved measurement of aerosol black carbon with real-time loading compensation. Atmos. Meas. Tech. 8, 1965-1979. https://doi.org/10.5194/ amt-8-1965-2015.

Forello, A.C., Bernardoni, V., Calzolai, G., Lucarelli, F., Massabò, D., Nava, S., Pileci, R.E., Prati, P., Valentini, S., Valli, G., Vecchi, R., 2019. Exploiting multi-wavelength aerosol absorption coefficients in a multi-time resolution source apportionment study to retrieve source-dependent absorption parameters. Atmos. Chem. Phys. 19, 11235-11252. https://doi.org/10.5194/acp-19-11235-2019.

Fröhlich, R., Crenn, V., Setyan, A., Belis, C.A., Canonaco, F., Favez, O., Riffault, V., Slowik, J.G., Aas, W., Aijälä, M., Alastuey, A., Artiñano, B., Bonnaire, N., Bozzetti, C., Bressi, M., Carbone, C., Coz, E., Croteau, P.L., Cubison, M.J., Esser-Gietl, J.K., Green, D.C., Gros, V., Heikkinen, L., Herrmann, H., Jayne, J.T., Lunder, C.R.,
Minguillón, M.C., Močnik, G., O’Dowd, C.D., Ovadnevaite, J., Petralia, E., Poulain, L., Priestman, M., Ripoll, A., Sarda-Estève, R., Wiedensohler, A. Baltensperger, U., Sciare, J., Prévôt, A.S.H., 2015. ACTRIS ACSM intercomparison Part 2: intercomparison of ME-2 organic source apportionment results from 15 individual, co-located aerosol mass spectrometers. Atmos. Meas. Tech. 8, 2555-2576. https://doi.org/10.5194/amt-8-2555-2015.

Goetz, J.D., Giordano, M.R., Stockwell, C.E., Christian, T.J., Maharian, R., Adhikari, S., Bhave, P.V., Praveen, P.S., Panday, A.K., Jayarathne, T., Stone, E.A., Yokelson, R.J., DeCarlo, P.F., 2018. Speciated online PM1 from South Asian combustion sources part 1: fuel-based emission factors and size distributions. Atmos. Chem. Phys. 18, 14653-14679. https://doi.org/10.5194/acp-18-14653-2018.

Hopke, P.K., 2016. Review of receptor modeling methods for source apportionment. J. Air Waste Manage. 66 (3), 237-259. https://doi.org/10.1080/ 10962247.2016.1140693.

IPCC, 2013. In: Stocker, T.F., Qin, D., Plattner, G.-K., Tignor, M., Allen, S.K., Boschung, J., Nauels, A., Xia, Y., Bex, V., Midgley, P.M. (Eds.), Climate Change 2013: the Physical Science Basis, Contribution of Working Group I to the Fifth Assessment Report of the Intergovernmental Panel on Climate Changes. Cambridge University Press, Cambridge, United Kingdom and New York, NY, USA. https://doi.org/ 10.1017/CBO9781107415324.

Jeong, C.H., Wang, J.M., Hilker, N., Debosz, J., Sofowote, U., Su, Y., Noble, M., Healy, R. M., Munoz, T., Dabek-Zlotorzynska, E., Celo, V., White, L., Audette, C., Herod, D., Evans, G.J., 2019. Temporal and spatial variability of traffic-related $\mathrm{PM}_{2.5}$ sources: comparison of exhaust and non-exhaust emissions. Atmos. Environ. 198, 55-69. https://doi.org/10.1016/j.atmosenv.2018.10.038.

Khlystov, A., Stanier, C., Pandis, S.N., 2004. An algorithm for combining electrical mobility and aerodynamic size distributions data when measuring ambient aerosol. Aerosol Sci. Technol. 38, 229-238. https://doi.org/10.1080/02786820390229543.

Kim, E., Hopke, P.K., Edgerton, E.S., 2003. Source identification of Atlanta aerosol by positive matrix factorization. J. Air Waste Manage 53, 731-739. https://doi.org/ 10.1080/10473289.2003.10466209.

Kuo, C.-P., Liao, H.-T., Chou, C.C.-K., Wu, C.-F., 2014. Source apportionment of particulate matter and selected volatile organic compounds with multiple time resolution data. Sci. Total Environ. 472, 880-887. https://doi.org/10.1016/j. scitotenv.2013.11.114.

Laskin, A., Laskin, J., Nizkorodov, S.A., 2015. Chemistry of atmospheric Brown carbon. Chem. Rev. 115, 4335-4382. https://doi.org/10.1021/cr5006167.

Lee, E., Chan, C.K., Paatero, P., 1999. Application of positive matrix factorization in source apportionment of particulate pollutants in Hong Kong. Atmos. Environ. 33, 3201-3212. https://doi.org/10.1016/S1352-2310(99)00113-2.

Liao, H.-T., Kuo, C.-P., Hopke, P.K., Wu, C.-F., 2013. Evaluation of a modified receptor model for solving multiple time resolution equations: a simulation study. Aerosol Air Qual. Res. 13, 1253-1262. https://doi.org/10.4209/aaqr.2012.11.0322.

Liao, H.-T., Chou, C.C.-K., Chow, J.C., Watson, J.G., Hopke, P.K., Wu, C.-F., 2015. Source and risk apportionment of selected VOCs and PM2:5 species using partially constrained receptor models with multiple time resolution data. Environ. Pollut. 205, 121-130. https://doi.org/10.1016/j.envpol.2015.05.035.

Lucarelli, F., Calzolai, G., Chiari, M., Giannoni, M., Mochi, D., Nava, S., Carraresi, L., 2014. The upgraded external-beam PIXE/PIGE set-up at LABEC for very fast measurements on aerosol samples. Nucl. Instr.Meth. B 318, 55-59. https://doi.org/ 10.1016/j.nimb. 2013.05.099.

Magee Scientific Aethalometer ${ }^{\circledR}$ Model AE33 - User Manual, Version 1.54, 2016.

Murphy, D.M., 2007. The design of single particle laser mass spectrometers. Mass Spectrom. Rev. 26, 150-165. https://doi.org/10.1002/mas.20113.

Ng, N.L., Herndon, S.C., Trimborn, A., Canagaratna, M.R., Croteau, P., Onasch, T.M., Sueper, D., Worsnop, D.R., Zhang, Q., Sun, Y.L., Jayne, T., 2011. An Aerosol Chemical Speciation Monitor (ACSM) for routine monitoring of the composition and mass concentrations of ambient aerosol. Aerosol Sci. Technol. 45, 770-784. https:// doi.org/10.1080/02786826.2011.560211.

Norris, G., Duvall, R., Brown, S., Bai, S., 2014. EPA Positive Matrix Factorization (PMF) 5.0. Fundamentals and User Guide. U.S. Environmental Protection Agency, Washington, DC.

Ogulei, D., Hopke, P.K., Zhou, L., Paatero, P., Park, S.S., Ondov, J.M., 2005. Receptor modeling for multiple time resolved species: the Baltimore supersite. Atmos. Environ. 39, 3751-3762. https://doi.org/10.1016/j.atmosenv.2005.03.012.

Paatero, P., Tapper, U., 1994. Positive matrix factorization: a non-negative factor model with optimal utilization of error estimates of data values. Environmetrics 5, 111-126. https://doi.org/10.1002/env.3170050203.

Paatero, P., 1999. The Multilinear Engine - a Table-drive least squares program for solving multilinear problems, including the n-way parallel factor analysis model. J. Comput. Graph Stat. 8, 854-888. https://doi.org/10.1080/ 10618600.1999 .10474853

Paatero, P., Hopke, P.K., 2009. Rotational tools for factor analytic models. J. Chemometr. 23, 91-100. https://doi.org/10.1002/cem.1197.

Paatero, P., 2010. User's guide for positive matrix factorization programs PMF2 and PMF3, part 2: reference. available at: https://www.helsinki.fi/ paatero/PMF/pmf2. zip (last access: 21 June 2018).

Paatero, P., 2012. The Multilinear Engine (ME-2) script language (v. 1.352), available with the program ME-2 (me2scrip.txt).

Paatero, P., 2015. User's guide for positive matrix factorization programs PMF2 and PMF3, part 1: Tutorial available at. https://www.helsinki.fi/ paatero/PMF/pmf2 zip (last access: 21 June 2018).

Paatero, P., 2018. Interactive comment on "Receptor modelling of both particle composition and size distribution from a background site in London, UK - the twostep approach” by David C. S. Beddows and Roy M. Harrison. https://doi.org/1 0.5194/acp-2018-784-RC2. 
Perrino, C., Canepari, S., Catrambone, M., Dalla Torre, S., Rantica, E., Sargolini, T., 2009. Influence of natural events on the concentration and composition of atmospheric particulate matter. Atmos. Environ. 43, 4766-4779. https://doi.org/10.1016/j. atmosenv.2008.06.035.

Perrino, C., Catrambone, M., Farao, C., Canepari, S., 2016. Assessing the contribution of water to the mass closure of $\mathrm{PM}_{10}$. Atmos. Environ. 140, 555-564. https://doi.org/ 10.1016/j.atmosenv.2016.06.038.

Perrino, C., Tofful, L., Dalla Torre, S., Sargolini, T., Canepari, S., 2019. Biomass burning contribution to $\mathrm{PM}_{10}$ concentration in Rome (Italy): seasonal, daily and two-hourly variations. Chemosphere 222, 839-848. https://doi.org/10.1016/j. chemosphere.2019.02.019.

Piazzalunga, A., Belis, C., Bernardoni, V., Cazzuli, O., Fermo, P., Valli, G., Vecchi, R. 2011. Estimates of wood burning contribution to PM by the macro-tracer method using tailored emission factors. Atmos. Environ. 45, 6642-6649. https://doi.org/ 10.1016/j.atmosenv.2011.09.08.

Polissar, A., Hopke, P.K., Paatero, P., Malm, W.C., Sisler, J.F., 1998. Atmospheric aerosol over Alaska: elemental composition and sources. J. Geophys. Res. 103, 19045-19057. https://doi.org/10.1029/98JD01212.

Reid, J.S., Koppmann, R., Eck, T.F., Eleuterio, D.P., 2005. A review of biomass burning emissions part II: intensive physical properties of biomass burning particles. Atmos. Chem. Phys. 5, 799-825. https://doi.org/10.5194/acp-5-799-2005.

Salzano, R., Pasini, A., Casasanta, G., Cacciani, M., Perrino, C., 2016. Quantitative interpretation of air Radon progeny fluctuations in terms of stability conditions in the atmospheric boundary layer. Boundary-Layer Meteorol. 160, 529-550. https:// doi.org/10.1007/s10546-016-0149-6.

Sandradewi, J., Prévôt, A.S.H., Szidat, S., Perron, N., Alfarra, M.R., Lanz, V.A. Weingartner, E., Balternsperger, U., 2008. Using aerosol light absorption measurements for the quantitative determination of wood burning and traffic emission contributions to particulate matter. Environ. Sci. Technol. 42, 3316-3323. https://doi.org/10.1021/es702253m.

Seinfeld, J.H., Pandis, S.N., 2006. Atmospheric Chemistry and Physics: from Air Pollution to Climate Change, second ed. JohnnWiley \& Sons, INC, Hoboken, New Jersey.

Sofowote, U.M., Healy, R.M., Su, Y., Debosz, J., Noble, M., Munoz, A., Jeong, C.-H., Wang, J.M., Hilker, N., Evans, G.J., Hopke, P.K., 2018. Understanding the PM2.5 imbalance between a far and near-road location: results of high temporal frequency source apportionment and parameterization of black carbon. Atmos. Environ. 173, 277-288. https://doi.org/10.1016/j.atmosenv.2017.10.063.

Srivastava, D., Favez, O., Petit, J.-E., Zhang, Y., Sofowote, U.M., Hopke, P.K., Bonnaire, N., Perraudin, E., Gros, V., Villenave, E., Albinet, A., 2019. Speciation of organic fractions does matter for aerosol source apportionment. Part 3: combining off-line and on-line measurements. Sci. Total Environ. 690, 944-955. https://doi. org/10.1016/jscitotenv.2019.06.378.
Struckmeier, C., Drewnick, F., Fachinger, F., Gobbi, G.P., Borrmann, S., 2016. Atmospheric aerosols in Rome, Italy: sources, dynamics and spatial variations during two seasons. Atmos. Chem. Phys. 16, 15277-15299. https://doi.org/10.5194/acp16-15277-2016.

Sunset Laboratory Inc, 2005. Semi-continuous OCEC Carbon Aerosol Analyzer, A Guide to Running and Maintaining the Sunset Laboratory Semi-continuous OCEC Analyser.

Thorpe, A., Harrison, R.M., 2008. Sources and properties of non-exhaust particulate matter from road traffic: a review. Sci. Total Environ. 400, 270-282. https://doi.org/ 10.1016/j.scitotenv.2008.06.007.

Tofful, L., Perrino, C., 2015. Chemical composition of indoor and outdoor PM2.5 in three schools in the city of Rome. Atmosphere 6, 1422-1443. https://doi.org/10.3390/ atmos6101422.

Ulbrich, I.M., Canagaratna, M.R., Zhang, Q., Worsnop, D.R., Jimenez, J.L., 2009. Interpretation of organic components from Positive Matrix Factorization of aerosol mass spectrometric data. Atmos. Chem. Phys. 9, 2891-2918. https://doi.org/ 10.5194/acp-9-2891-2009.

U.S. EPA (Environmental Protection Agency), 2011. Office of air quality planning and standards, air quality assessment division, ambient air monitoring group: Sunset carbon evaluation project. Quality Assurance Project Plan (QAPP), Version 1.

Valentini, S., Barnaba, F., Bernardoni, V., Calzolai, G., Costabile, F., Di Liberto, L., Forello, A.C., Gobbi, G.P., Gualtieri, M., Lucarelli, F., Nava, S., Petralia, E., Valli, G., Wiedensohler, A., Vecchi, R., 2020. Classifying aerosol particles through the combination of optical and physical-chemical properties: results from a wintertime campaign in Rome (Italy). Atmos. Res. 235, 104799. https://doi.org/10.1016/j. atmosres.2019.104799.

Vecchi, R., Piziali, F.A., Valli, G., Favaron, M., Bernardoni, V., 2019. Radon-based estimates of equivalent mixing layer heights: a long-term assessment. Atmos. Environ. 197, 150-158. https://doi.org/10.1016/j.atmosenv.2018.10.020.

WHO, 2018. Global Ambient Air Quality Database. Update May 2018. Department of Public Health, Environmental and Social Determinants of Health (PHE), World Health Organization, Geneva, Switzerland. available at: https://www.who.int/ai rpollution/data/en/ (last access: March 2020).

Zhou, L., Hopke, P.K., Paatero, P., Ondov, J.M., Pancras, J.P., Pekney, N.J., Davidson, C. I., 2004. Advanced factor analysis for multiple time resolution aerosol composition data. Atmos. Environ. 38, 4909-4920. https://doi.org/10.1016/j. atmosenv.2004.05.040.

Zotter, P., Herich, H., Gysel, M., El-Haddad, I., Zhang, Y., Močnik, G., Hüglin, C., Baltensperger, U., Szidat, S., Prévôt, A.S.H., 2017. Evaluation of the absorption Ångström exponents for traffic and wood burning in the Aethalometer-based source apportionment using radiocarbon measurements of ambient aerosol. Atmos. Chem. Phys. 17, 4229-4249. https://doi.org/10.5194/acp-17-4229-2017. 